\title{
HYBRIDITY VERSUS REVIVABILITY: MULTIPLE CAUSATION, FORMS AND PATTERNS
}

Ghil'ad Zuckermann

\author{
Associate Professor and ARC Discovery Fellow in Linguistics \\ The University of Queensland, Australia
}

\begin{abstract}
The aim of this article is to suggest that due to the ubiquitous multiple causation, the revival of a no-longer spoken language is unlikely without cross-fertilization from the revivalists' mother tongue(s). Thus, one should expect revival efforts to result in a language with a hybridic genetic and typological character. The article highlights salient morphological constructions and categories, illustrating the difficulty in determining a single source for the grammar of Israeli, somewhat misleadingly a.k.a. 'Modern Hebrew'. The European impact in these features is apparent inter alia in structure, semantics or productivity. Multiple causation is manifested in the Congruence Principle, according to which if a feature exists in more than one contributing language, it is more likely to persist in the emerging language. Consequently, the reality of linguistic genesis is far more complex than a simple family tree system allows. 'Revived' languages are unlikely to have a single parent. The multisourced nature of Israeli and the role of the Congruence Principle in its genesis have implications for historical linguistics, language planning and the study of language, culture and identity.
\end{abstract}

\footnotetext{
"Linguistic and social factors are closely interrelated in the development of language change. Explanations which are confined to one or the other aspect, no matter how well constructed, will fail to account for the rich body of regularities that can be observed in empirical studies of language behavior."
}

Weinreich, Labov \& Herzog 1968: 188.

\section{Introduction}

'Israeli' (Zuckermann, 1999) - also known as 'Modern Hebrew'-is currently one of the 2.5 official languages (together with Arabic, English being a de facto but not an official language) of the State of Israel (established in 1948) and is spoken to varying degrees of fluency by Israeli citizens (more than 7 million): as a mother tongue by most Israeli Jews (whose total number 
exceeds 5 million), and as a second language by Israeli Muslims (Arabic-speakers), Christians (e.g. Russian- and Arabic-speakers), Druze (Arabic-speakers) and others. During the past century, Israeli has become the primary mode of communication in all domains of public and private life among Israeli Jews.

Israeli possesses distinctive socio-historical characteristics such as the lack of a continuous chain of native speakers from spoken Hebrew to Israeli, the non-Semitic mother tongues spoken by the revivalists, and the European impact on literary Hebrew. Consequently, it presents the linguist with a fascinating and multifaceted laboratory in which to examine a wider set of theoretical problems concerning language genesis, social issues like language and politics, and practical matters, e.g. whether it is possible to revive a no-longer spoken language. The multisourced nature of Israeli and the role of the CONGRUence Principle $(\S 1.5)$ and the Founder Principle ( $\$ 1.4)$ in its genesis have implications for historical linguistics, language planning, creolistics and the study of grammars in contact.

The aim of this article is to propose that - due to the ubiquitous multiple causation (see the sociolinguistic quote above from Weinreich, Labov \& Herzog, 1968: 188, as well as Dorian, 1993) - the revival of a no-longer spoken language is unlikely without cross-fertilization from the revivalists' mother tongue(s). Thus, revival efforts result in a language with a hybridic genetic and typological character. I shall highlight salient morphological constructions and categories, illustrating the difficulty in determining a single source for Israeli grammar. The European impact in these features is apparent inter alia in structure, semantics or productivity. Being a journal article rather than a lengthy book, this paper does not attempt to be grammatically exhaustive but rather to cast new light on the partial success of language revival in general and on the genetics of Israeli in particular.

Multiple causation is manifested in the Congruence Principle, according to which if a feature exists in more than one contributing language, it is more likely to persist in the emerging language. This article discusses multiple causation in (1) constituent order, (2) tense system, (3) copula enhancement, (4) calquing, and (5) phono-semantic matching in 'Israeli' (Zuckermann 1999, somewhat misleadingly a.k.a. 'Revived Hebrew' / 'Modern Hebrew'). It suggests that the reality of linguistic genesis is far more complex than a simple family tree system allows. 'Revived' languages are unlikely to have a single parent.

Generally speaking, whereas most forms of Israeli are Semitic, many of its patterns are European. It is proposed that (1) Whereas Hebrew was synthetic, Israeli-following Yiddish etc.is much more analytic; (2) Israeli is a habere language (cf. Latin habere 'to have', taking the direct object), in stark contrast to Hebrew; (3) European languages sometimes dictate the gender of Israeli coinages; (4) The (hidden) productivity and semantics of the allegedly completely Hebrew system of Israeli verb-templates are, in fact, often European; (5) In Hebrew there was a polarity-of-gender agreement between nouns and numerals, e.g. 'éser banót 'ten girls' versus 'asar-á baním 'ten (feminine) boys'. In Israeli there is a simpler-European — system, e.g. éser banót 'ten girls', éser banim 'ten boys'; (6) Yiddish has shaped the semantics of the Israeli verbal system in the case of inchoativity; (7) Following 'Standard Average European', the Israeli proclitics be- 'in', le- 'to' and $m i-/ m e$ 'from', as well as the coordinating conjunction ve- 'and', are phonologically less dependent than in Hebrew; (8) Word-formation in Israeli abounds with European mechanisms such as portmanteau blending.

Israeli possesses distinctive socio-historical characteristics such as the lack of a continuous chain of native speakers from spoken Hebrew to Israeli, the non-Semitic mother tongues spoken by the revivalists, and the European impact on literary Hebrew. Consequently, it presents the linguist with a fascinating and multifaceted laboratory in which to examine a wider set of theoretical problems concerning language genesis and hybridity, social issues like language vis-à-vis politics, and 
practical matters, e.g. whether it is possible to revive a no-longer spoken language. The multisourced nature of Israeli and the role of the Congruence Principle in its genesis have implications for historical linguistics, language planning and the study of language, culture and identity.

\subsection{Proposed periodization of Hebrew and Israeli}

Hebrew was spoken after the so-called conquest of Canaan (c. thirteenth century BC). It belonged to the Canaanite division of the north-western branch of Semitic languages. Following a gradual decline, it ceased to be spoken by the second century AD. The failed Bar-Kohhba Revolt against the Romans in Judaea in $\mathrm{AD}$ 132-5, in which thousands of Hebrew speakers were exterminated, marks the symbolic end of the period of spoken Hebrew. But the actual end of spoken Hebrew might have been earlier. Jesus, for example, was a native speaker of Aramaic rather than Hebrew. For more than 1700 years thereafter, Hebrew was comatose. It served as a liturgical and literary language and occasionally also as a lingua franca for Jews of the Diaspora, but not as a mother tongue.

Periodization of Hebrew is not an easy task. Biblical Hebrew (c. tenth through first centuries BC) is the Hebrew of the Old Testament and of inscriptions from the First Temple period. Its use spanned three main periods: (i) Archaic Biblical Hebrew: Pentateuch and the Early Prophets; (ii) Standard Biblical Hebrew: The prose preceding the Babylonian Exile (597-538 BC); and (iii) Late Biblical Hebrew: Chronicles and other later books of the Hebrew Bible composed between the period after the Babylonian Exile and the birth of Rabbinic Judaism (Pharisees). There are also 'minimalist' views, according to which all the Hebrew Bible books were written at the same time, e.g. in the fifth century BC. Anyway, although the relationship between the written language of the Bible and the actual language spoken at the time is unclear, I believe that Hebrew was a mother tongue when the Bible was written.

This may not be the case with Mishnaic Hebrew, sometimes known as Rabbinic Hebrew (c. first century BC through sixth century AD), which consisted of the Mishnah (Rabbinic interpretation of the Pentateuch) and (the Hebrew parts of) the Palestinian and Babylonian Talmud (including the Gemara, which consists of discussions on the Mishnah). I propose that the Mishnah was written in the first and second centuries AD because the Tannaim (e.g. Hillel, Shammai, Rabbi Akiba and Simeon Bar Yohai) realized that Hebrew was dying, and feared the loss of oral tradition.

Medieval Hebrew(s) refers to the varieties of literary Hebrew in the Middle Ages (c. sixth through $c$. seventeenth/eighteenth centuries): piyyutim 'liturgical poems', scientific writings, interpretation and Rabbinic literature. There are various views concerning the time at which socalled Modern Hebrew began. The most comprehensive solution was suggested by W. Chomsky (1967: 206-11), who maintained that there was a 'transitional period' from Medieval Hebrew to Modern Hebrew (the latter in this case meaning Israeli). This transitional period lasted between the Jewish medieval 'Golden Age' in Spain and the 'Hebrew revival' in Eretz Yisrael ('Land of Israel', Palestine), and included early modern Hebrew literature in Italy, as well as the German Haskalah (lit. 'intellect', referring to the 1770-1880 Enlightenment Movement), led by Moses Mendelssohn and Naphtali Herz Wessely. Almost all the dates suggested by others for the beginnings of the language fall within this transitional period (Zuckermann, 2008a).

Unlike Maskilic Hebrew (i.e. the Hebrew of the Haskalah), a literary language, Israeli is a living mother tongue. Its formation was facilitated in Eretz Yisrael only at the end of the nineteenth century by the most famous revival ideologue Eliezer Ben-Yehuda (1858-1922), school teachers and enthusiastic supporters. Itamar Ben-Avi (1882-1943, born as Ben-Zion Ben-Yehuda), Eliezer Ben-Yehuda's son, is symbolically considered to have been the first native Israeli-speaker. He was born one year after Eliezer Ben-Yehuda, a native Yiddish-speaker, conversant in Russian and French, arrived in Eretz Yisrael. 
Almost all 'revivalists' - e.g. the symbolic father of Israeli, Eliezer Ben-Yehuda, born Perelman - were native Yiddish-speakers who wanted to speak Hebrew, with Semitic grammar and pronunciation, like Arabs. Not only were they European but their revivalist campaign was inspired by European - e.g. Bulgarian - nationalism. At the time, although territory and language were at the heart of European nationalism, the Jews possessed neither a national territory nor a national language. Zionism could be considered a fascinating manifestation of European discourses channeled into the Holy Land - cf. George Eliot's Daniel Deronda (1876).

But it was not until the beginning of the twentieth century that Israeli was first spoken by a community, which makes it approximately 100 years old. The first children born to two Israelispeaking parents were those of couples who were graduates of the first Israeli schools in Eretz Yisrael, and who had married in the first decade of the twentieth century (Rabin, 1981: 54). In April 2000, the oldest native Israeli-speaker was Dola Wittmann (in her late 90s), Eliezer Ben-Yehuda's daughter, who also happens to be one of the first native Israeli-speakers.

Ben-Yehuda would have been most content had Israelis spoken Biblical Hebrew, which he (and many others) considered the 'purest' form of Hebrew. The Sephardic pronunciation-e.g. with 'more Semitic' consonants and word final stress-was preferred to the Ashkenazic one. But as Zuckermann (2005) demonstrates, Israeli phonology and phonetics are by and large European rather than Semitic. Compare, for example, the Hebrew syllable structure $\mathrm{CV}(\mathrm{X})(\mathrm{C})$ with the Israeli one: $(\mathrm{s} / \mathrm{sh})(\mathrm{C})(\mathrm{C}) \mathrm{V}(\mathrm{C})(\mathrm{C})(\mathrm{s} / \mathrm{sh})$. Or juxtapose the Hebrew pharyngealized (emphatic) consonants $\mathrm{P}[\mathrm{q}], \mathrm{v}$ $\left[\mathrm{t}^{\mathrm{S}}\right]$ and $\mathrm{Y}\left[\mathrm{s}^{\mathrm{S}}\right]$ with their phonetic realization in Israeli: $[\mathrm{k}],[\mathrm{t}]$ and $[\widehat{\mathrm{t}}]$. Or the Hebrew alveolar trill \urcorner$[\mathrm{r}]$, realized phonetically in Israeli as a lax uvular approximant $[\underset{\mathrm{\sigma}}{\mathrm{b}}]$ — despite huge efforts by the Hebrew normativists to eradicate it (Zuckermann, 2005).

Ben-Yehuda's numerous neologisms were often based on Semitic languages such as Arabic. For example, Israeli ribá 'jam' was coined by Ben-Yehuda in 1888 on the basis of Arabic [mu'rabba] 'jam' (from r.b.b.), as though it derived from Hebrew r.b.b. Similarly, Israeli ahád 'liked, sympathized (msg)' was Ben-Yehuda's 'phono-semantic matching of Arabic ['ha:wada] 'returned to, made peace with, felt sympathy towards, complied (with the humour of) (msg)' - cf. also Israeli ahadá 'sympathy', Ben-Yehuda's 1899 parallel to Arabic [ha'wa:da] 'complaisance, clemency, sympathy, indulgence'. The rationalization might have been the Hebrew Biblical names [?e'hūd] (Judges 3:15) and ['Pohad] (Genesis 46:10) (the current pronunciation is the quasi-hypercorrect ohád) (Zuckermann, 2003: 215).

The following sequence (Figure 1) depicts my proposed new periodization for both Hebrew and Israeli. One should acknowledge literary overlaps between the various phases. For example, the twentieth-century author Shmuel Yosef Agnon wrote in a non-native variant of Hebrew (largely Mishnaic) rather than in Israeli (his mother tongue being Yiddish). In fact, Israeli literature can be put on a continuum from literary Israeli (e.g. Etgar Keret) to literary Hebrew (e.g. Shmuel Yosef Agnon) but this linguistic article is mostly concerned with the vernacular.

Furthermore, none of the so-called 'periods' in the history of Hebrew is clearly delineated. More than one 'Hebrew' - e.g. Biblical, Mishnaic and Medieval - may have coexisted with another one at any one time. In fact, Israelis tend and are taught to perceive the various Hebrews as one language. 


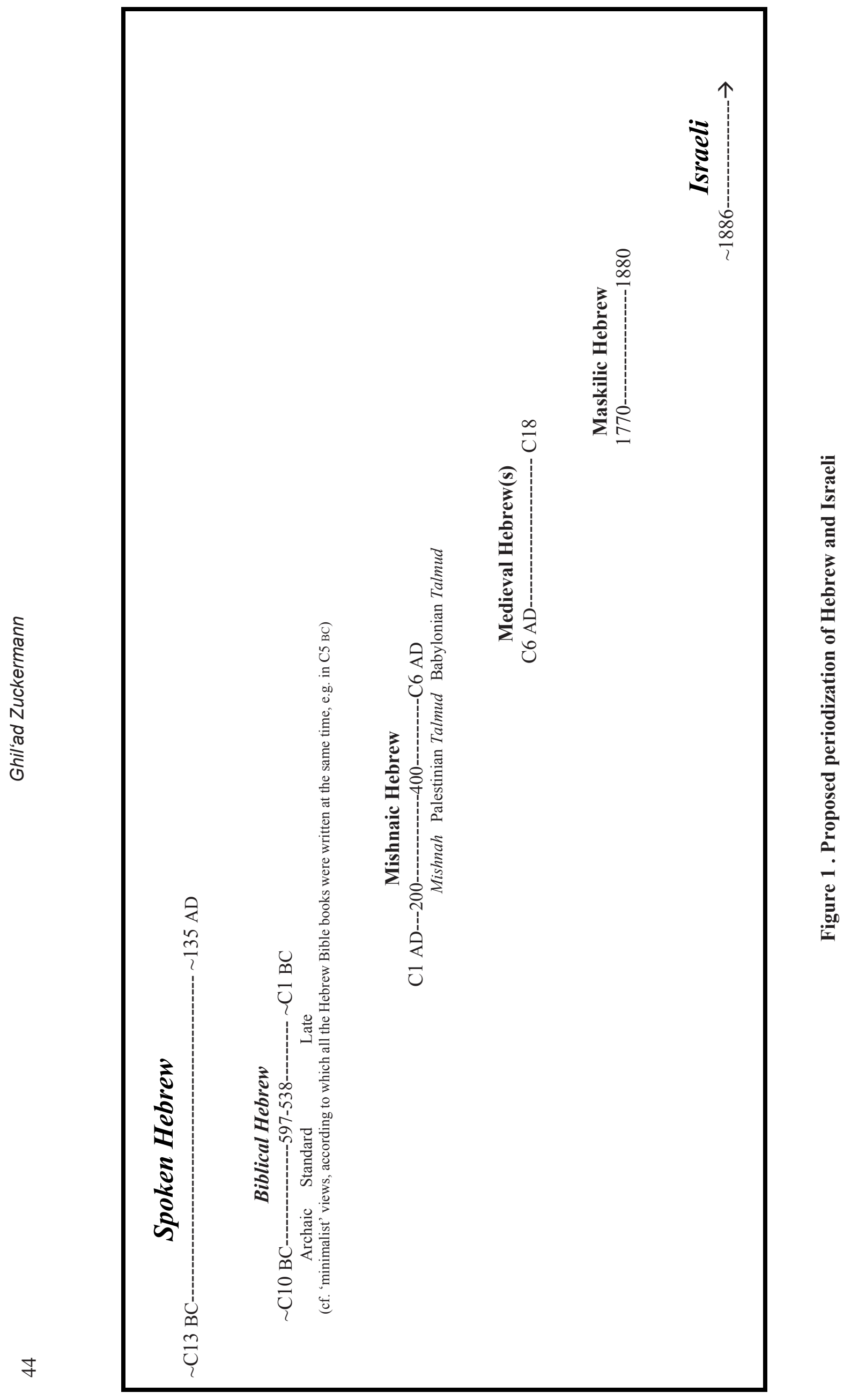




\subsection{The genetic classification of Israeli}

The genetic classification of Israeli has preoccupied scholars since the beginning of the twentieth century. The still regnant (not to mention politically pregnant) traditional view suggests that Israeli is Semitic: (Biblical/Mishnaic) Hebrew revived (e.g. Rabin, 1974). The revisionist position defines Israeli as Indo-European: Yiddish relexified, i.e. Yiddish, most revivalists' máme lóshn (mother tongue), is the substrate, whilst Hebrew is the superstrate providing lexicon and frozen, fossilized, lexicalized morphology (Horvath \& Wexler, 1997).

From time to time it is alleged that Hebrew never died (Haramati, 1992, 2000, Chomsky, 1957: 218). It is true that, throughout its literary history, Hebrew was used as an occasional lingua franca. However, between the second and nineteenth centuries it was no one's mother tongue, and I believe that the development of a literary language is very different from that of a fully-fledged native language. But there are many linguists who, though rejecting the 'eternal spoken Hebrew mythology', still explain every linguistic feature in Israeli as if Hebrew never died. For example, Goldenberg (1996: 151-8) suggests that Israeli pronunciation originates from internal convergence and divergence within Hebrew.

I wonder, however, how a literary language can be subject to the same phonetic and phonological processes (rather than analyses) as a mother tongue. I argue, rather, that the Israeli sound system continues the (strikingly similar) phonetics and phonology of Yiddish, the native language of almost all the revivalists. Unlike the traditionalist and revisionist views, my own hybridizational model acknowledges the historical and linguistic continuity of both Semitic and Indo-European languages within Israeli. Hybridic Israeli is based simultaneously on Hebrew and Yiddish (both being primary contributors), accompanied by a plethora of other contributors such as Russian, Polish, German, Judaeo-Spanish ('Ladino'), Arabic and English. Therefore, the term 'Israeli' is far more appropriate than 'Israeli Hebrew', let alone 'Modern Hebrew' or 'Hebrew' (tout court), since any signifier including the term Hebrew gives the linguistically and historically wrong impression that Israeli is an organic evolution of Hebrew, whereas it was created ab initio in a hybridic genesis. Figure 2 illustrates the intricate genesis of Israeli $(\rightarrow$ representing either contribution or influence):

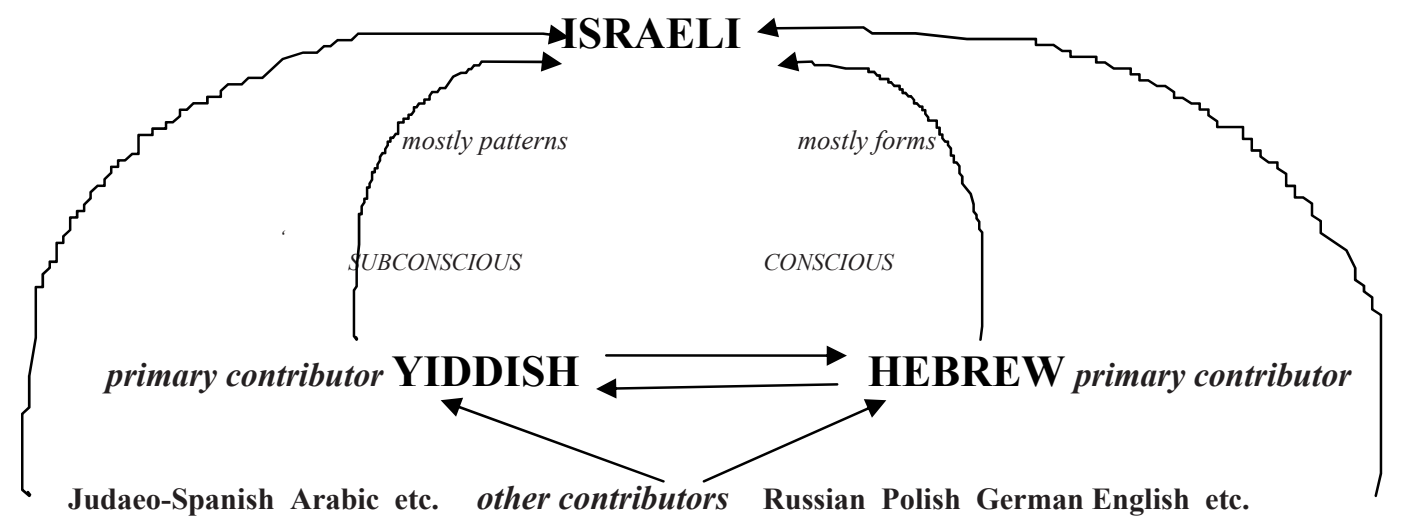

Figure 2 . My hybridizational model of Israeli genesis 
From the point of view of development of ideas and history of linguistics, I would like to propose that whereas the traditional revival view is the THESIS, and the relexification view is the ANTITHESIS, my own hybridization model is the SYNTHESIS. Whilst I reject both the thesis and the antithesis, I acknowledge some insights from both of them. I believe that my synthesis will eventually become the new thesis, subject to a new antithesis and so forth.

What makes the 'genetics' of Israeli grammar so complex, thus supporting my synthetic model, is the fact that the combination of Semitic and Indo-European influences is a phenomenon occurring already within the primary (and secondary) contributors to Israeli. Yiddish, a Germanic language with a Latin substrate (and with most dialects having been influenced by Slavonic languages), was shaped by Hebrew and Aramaic. On the other hand, Indo-European languages, such as Greek, played a role in pre-Medieval varieties of Hebrew (see, for example, Hellenisms in the Old Testament). Moreover, before the emergence of Israeli, Yiddish and other European languages influenced Medieval and Maskilic variants of Hebrew (Glinert, 1991), which, in turn, shaped Israeli (in tandem with the European contribution). This adds to the importance of the Congruence Principle (§1.5).

The obvious competing hypothesis is the classical language contact analysis, according to which Israeli is (axiomatically) Hebrew (revived) with extensive influence from Yiddish, as well as other European languages spoken by its creators. I hope that this article weakens the viability of such a hypothesis, which to me sounds implausible even if only from a historical sequence perspective. If the phonology, phonetics - and in fact all linguistic components - of Israeli were shaped by European languages in the revival process, I wonder why one should argue that Israeli is Hebrew influenced by Yiddish. Such a contact linguistic analysis may suit Modern Italian, influenced by American English but how can one expect it to suit the case here in which neither Israeli nor Hebrew were mother tongues between the second and the nineteenth centuries AD? In other words, Israeli is not a simple case of Hebrew with an 'imposition' (van Coetsem, 1988, 2000, as well as Winford, 2005).

Obviously, I cannot argue that every revived language must be hybridic. But given that the Hebrew revivalists, who wished to speak pure Hebrew, failed in their purism, it is simply hard to imagine more successful revival attempts. It would be hard to compete with the Hebrew revival for the following two components: (1) the remarkable strength of the revivalists' motivation, zealousness, Hebrew consciousness, and centuries of 'next year in Jerusalem' ideology, and (2) the extensive documentation of Hebrew (as opposed to, say, 'sleeping' (i.e. 'dead') Australian Aboriginal languages). At the very least, this article should make linguists refrain from referring to Israeli as a case of complete language revival. I believe that Israeli does include numerous Hebrew elements resulting from a conscious revival but also numerous pervasive linguistic features deriving from a subconscious survival of the revivalists' mother tongues, e.g. Yiddish.

\subsection{The Founder Principle}

Most revivalists were Yiddish-speaking Ashkenazim. Furthermore, as indicated by sfirát yehudéy érets yisraél, a census conducted in 1916-18 (Bachi, 1956: 67-9), the Ashkenazim were the ones most receptive to the 'Hebrew revival': $61.9 \%$ of Ashkenazic children and $28.5 \%$ of Ashkenazic adults spoke Israeli in 1916-18. The percentage of Israeli-speakers among Sephardim (constituting most of the veteran residents in Eretz Yisrael) and the other mizrahim (excluding the Yemenites, Jews originating from the Yemen) was low: only 18.3\% of Sephardic children and $8.4 \%$ of Sephardic adults spoke Israeli in 1916-18, whilst 18.1\% of mizrahi children (excluding Sephardim and Yemenites) and $7.3 \%$ of mizrahi adults spoke Israeli (cf. 53.1\% among Yemenite children and 37.6\% among Yemenite adults). To obtain an idea of the approximate 'real' numbers, one should note that between 1850 and 1880 approximately 25,000 Jews immigrated into Eretz 
Yisrael (mostly Ashkenazim), in 1890 a total of only 40,000 Jews lived in Eretz Yisrael—see Bachi (1977: 32, 77). Between 1881 and 1903 20,000-30,000 Jews arrived in Eretz Yisrael (ibid.: 79).

I propose that had the revivalists and their followers been Arabic-speaking Jews (e.g. from Morocco), Israeli would have been a totally different language - both genetically and typologically, much more Semitic. The impact of the founder population on Israeli is much more significant than that of later immigrants, no matter how large the latter have been. For example, the influence of several hundreds of Russian-speakers at the beginning of Israeli was significantly larger than that of one million Russian-speakers arriving in Israel at the end of the twentieth century.

The following is how Zelinsky (1973: 13-14) describes the influence of first settlements, from the point of view of cultural geography:

\begin{abstract}
Whenever an empty territory undergoes settlement, or an earlier population is dislodged by invaders, the specific characteristics of the first group able to effect a viable selfperpetuating society are of crucial significance to the later social and cultural geography of the area, no matter how tiny the initial band of settlers may have been [...] in terms of lasting impact, the activities of a few hundred, or even a few score, initial colonizers can mean much more for the cultural geography of a place than the contributions of tens of thousands of new immigrants generations later.
\end{abstract}

Harrison et al. (1988) discuss the 'Founder Effect' in biology and human evolution, and Mufwene (2001) applies it as a creolistic tool to explain why the structural features of so-called creoles are largely predetermined by the characteristics of the languages spoken by the founder population, i.e. by the first colonists. I propose the following application of the Founder Principle in the context of Israeli:

Yiddish is a primary contributor to Israeli because it was the mother tongue of the vast majority of revivalists and first pioneers in Eretz Yisrael at the crucial period of the beginning of Israeli.

The Founder Principle works because by the time later immigrations came to Israel, Israeli had already entrenched the fundamental parts of its grammar. Thus, Moroccan Jews arriving in Israel in the 1950s had to learn a fully-fledged language. The influence of their mother tongue on Israeli was relatively negligible. Wimsatt's (1999a, 1999b) notion of 'generative entrenchment' is of relevance here. (Although the Founder Principle refers to an obvious, long-known fact, there are cases pointing otherwise, e.g. the influence of a late wave of African slaves on the structure of Haitian Creole; see Singler (1995).)

At the same time - and unlike anti-revivalist revisionists-I suggest that liturgical Hebrew too fulfills the criteria of a primary contributor for the following reasons: (i) Despite millennia without native speakers, Hebrew persisted as a most important cultural, literary and liturgical language throughout the generations; (ii) Zionist revivalists were extremely ideological and made a huge effort to revive Hebrew and were, in fact, partly successful.

The focus of this article is morphology (and syntax). Elsewhere, I discuss the impact of Yiddish and other European languages on Israeli lexis, word-formation and semantics (Zuckermann, 1999, 2003, 2004), phonetics and phonology (Zuckermann, 2005, 2008a), complementation (Zuckermann, 2006a) and reported speech (Zuckermann, 2006b). By and large, whilst Israeli phonology and phonetics are mostly European (Zuckermann, 2005), its morphological forms and basic vocabulary are mainly—albeit not exclusively_-Semitic. Figure 3 illustrates this generalization: 


'Genius/Spirit/Mindset'
Phonology Phonetics
Semantics Morphology Syntax
Lexis $\quad \rightarrow \quad \leftarrow \quad$ Revivable

(European)

(Semitic)

\section{Figure 3 . A tentative cline of revivability}

Phonology is claimed to be less revivable than phonetics because intonation, for example, is less revivable than a specific consonant. Within semantics, connotations and associations are less revivable than senses. On 'genius', 'spirit' or 'mindset' - cf. relexification in Horvath \& Wexler (1997), as well as Dawkins (1916) on Asia Minor Greek: 'the body has remained Greek, but the soul has become Turkish (italics mine, cf. Thomason \& Kaufman 1988: 65). Clearly, some scholars may find these metaphors inappropriate but perhaps we should not ignore what they refer to only because it is unquantifiable. Lack of measurability should not automatically result in ignoring.

\subsection{The Congruence Principle}

My lexicological research (Zuckermann, 2003) has strengthened the importance of the Congruence Principle (Zuckermann, 2006c, 2008a):

If a feature exists in more than one contributing language,

it is more likely to persist in the emerging language.

This principle is applicable to all languages and indeed to linguistic evolution in general. After all, every language is mixed to some extent (Hjelmslev, 1938, as well as Schuchardt's, 1884 'Es gibt keine völlig ungemischte Sprache'). Such congruence is a commonplace observation in pidgin and creole studies, as well as in research into many other languages. Kerswill (2002) describes how features found in several varieties are the most likely to survive in koine formation.

This article argues that the Congruence Principle can be profitably used also to allow for grammatical features of Israeli. Hebrew grammatical features which - either serendipitously or due to an earlier Indo-European influence (see §1.3)—were congruent with those of Yiddish and other European languages were favoured, and vice versa.

\subsection{Forms versus patterns}

The distinction between forms and patterns is crucial too as it demonstrates multiple causation. In the 1920s and 1930s, gdud meginéy hasafá, 'the language defendants regiment' (Shur, 2000), whose motto was ivrí, dabér ivrit 'Hebrew [i.e. Jew], speak Hebrew!', used to tear down signs written in 'foreign' languages and disturb Yiddish theatre gatherings. However, the members of this group only looked for Yiddish forms, rather than patterns in the speech of the Israelis who did מה מש choose to speak 'Hebrew'. The language defendants would not attack an Israeli speaker saying má nishmà, lit. 'What does one hear? / What is heard?', i.e. 'How are you?', 'What's up?',

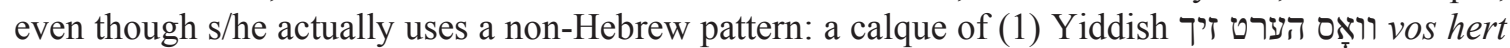
$z i k h$, lit. 'What does one hear?', i.e. 'How are you?', 'What's up?', (2) Russian Что слышно chto slýshno 'id.', (3) Polish Co stychać 'id.' and (4) Romanian Ce se aude 'id.' (see §2.12).

Israeli patterns have often been based on Yiddish, Russian, Polish and sometimes 'Standard Average European'. The term 'Standard Average European', henceforth SAE, was first introduced 
by Whorf (1941: 25) and recently received more attention from Haspelmath $(1998,2001)$ and Bernini \& Ramat (1996) - cf. 'European Sprachbund' in Kuteva (1998). I use this term only occasionally when it so happens that Yiddish, Russian, Polish and other European languages contributing to Israeli have a feature which has already been identified in the research as SAE.

This is, obviously, not to say that the revivalists, had they paid attention to patterns, would have managed to neutralize the impact of their mother tongues, which was very often subconscious. Although they engage in a campaign for linguistic purity (they wanted Israeli to be Hebrew, despising the Yiddish 'jargon' and negating the Diaspora and the diasporic Jew; see Zuckermann, 2008a), the language revivalists create is very likely to mirror the very hybridity and foreign impact they seek to erase (Israeli is both Semitic and Indo-European). The 'revivalists' attempts (1) to deny their (more recent) roots in search of Biblical ancientness, (2) negate diasporism and disown the 'weak, dependent, persecuted' exilic Jew, and (3) avoid hybridity (as reflected in Slavonized, Romance/Semitic-influenced, Germanic Yiddish itself, which they despised) failed.

This article proposes that in the case of 'revived' languages such as Israeli, whereas the language's forms are much looked over (i.e. ignored), its patterns are overlooked. For example, the (hidden) productivity and semantics of the allegedly completely Hebrew system of Israeli verbtemplates (the latter are regarded here as Semitic forms - as opposed to their semantic patterns) are often Europeanized. Generally speaking, whereas most forms of Israeli are Semitic, many of its patterns are European. Figure 4 illustrates this observation:

\section{European $\leftarrow$ Patterns $\quad$ Forms $\rightarrow$ Semitic}

Figure 4 . Semitic forms cum European patterns

This is not to say that Israeli does not have European forms (but these are outside the basic vocabulary - cf. the productive English -able/-ible - and obviously cannot alone prove hybridity). In addition to thousands of common lexical items of non-Semitic descent, Israeli abounds with various non-Semitic derivational affixes, which are applied to words of both Semitic and non-Semitic descent. Consider the following words consisting of a Hebrew-descent word and a non-Semiticdescent suffix: khamúda-le 'cutie (fsg)', from khamuda 'cute (fsg) + -le, endearment diminutive of Yiddish descent; miluim-nik 'reservist, reserve soldier', from miluim 'reserve' (lit. 'fill-ins') + -nik, a most productive agent suffix of Yiddish and Russian descent; bitkhon-ist 'one who evaluates everything from the perspective of national security', from bitakhón 'security' + the productive internationalism -ist; kiso-lógya 'the art of finding a political seat (especially in the Israeli Parliament)', from kisé 'seat' + the productive internationalism -lógya '-logy'; maarav-izátsya 'westernization' (from maaráv 'west' + the productive internationalism -izátsya '-ization'). Examples of Israeli words which include an international prefix are post-milkhamti 'postwar', proaravi 'pro-Arab', anti-hitnatkút 'anti-disengagement'.

Consider also the productive derogatory prefixal phonestheme $s h m$-, which results in an 'echoic expressive' (Haig, 2001: 208-9). For example, um shmum, lit. 'UN shm-UN', was a pejorative description by Israel's first Prime Minister, David Ben-Gurion, of the United Nations. When an Israeli speaker would like to express his impatience with or disdain for philosophy, s/he can say filosófya-shmilosófya. Israeli shm- is traceable back to Yiddish. (Cf. the Turkic initial $m$-segment conveying a sense of 'and so on' as in Turkish dergi mergi okumuyor, lit. "magazine "shmagazine" read:NEG:PRES: 3sg', i.e. '(He) doesn't read magazine, journals or anything like that' (Haig, 2001: 209; Lewis, 1967: 237).) 
Another Yiddish-descent linguistic device to convey impatience is the 'involvement discourse marker' nu as in Israeli nú kvar (< Yiddish nu shoyn) and nu bemét, lit. 'nu, in-truth', meaning 'stop it' or 'what kind of behavior is that!'. Maschler (1994) finds that this is the second-most prevalent interpersonal discourse marker. Among its functions are (i) hastening a nonverbal action, (ii) urging further development within a topic, (iii) granting permission to perform an action, and (iv) providing a joking/provoking tone (Maschler, 2003).

\section{Grammatical characteristics}

In the following sections I highlight salient morphological (and syntactic) constructions and categories, illustrating the difficulty in determining a single source for Israeli grammar. The European impact in these features is apparent in structure, semantics or productivity. Obviously, due to a lack of space, the survey is not exhaustive.

\subsection{Analytic Israeli}

Whereas Hebrew was synthetic, Israeli is much more analytic, both with nouns and with verbs. Muchnik (2004) demonstrates that literary Israeli (i.e. the language of Israeli literature and newspapers - cf. diglossia in \$2.6) shows a clear preference for analytic grammatical constructions. I suggest that the analyticization of literary Israeli is due to the influence of spoken Israeli, which$a b$ initio, owing to the European contribution-has been much more analytic than has hitherto been admitted. The tendency towards analytic structures is correlated with language contact; see McWhorter (2002). But Israeli was more analytic than Hebrew ab initio rather than as a result of analyticization due to post-genesis language contact.

Consider the construct-state (CONSTR), the Semitic N-N structure in which two nouns are combined, the first being modified or possessed by the second:

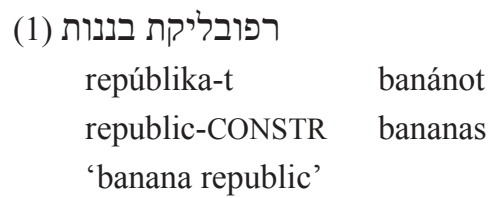

Unlike in Hebrew, construct-state indicating possession is not productive in Israeli. Compare the Hebrew construct-state 'em ha-yéled 'mother- DEF-child' with the more analytic Israeli phrase haima shel ha-yéled 'DEF-mother GEN DEF-child', both meaning 'the mother of the child', i.e. 'the child's mother'.

One might argue that the weakening of the construct-state occurs only in possessive constructstates but not in others. But many 'compound' construct-states are not treated as construct-states either; they are lexicalized and treated as one word. Thus, although orekh din, lit. 'arranger- law', i.e. 'lawyer', is historically a construct-state, there are several indications that it is not so anymore: (i) the stress has changed from orékh din to òrekh din; (ii) when definite, the definite article haprecedes it rather than appearing between the two nouns: ha-òrekh dín, lit. 'DEF arranger- law' rather than Hebrew 'orékh ha-dín, lit. 'arranger- DEF law'.

\begin{tabular}{lllc} 
(2) HEBREW עורך דין & עורך הדין & \\
& 'orékh dín & 'orékh & ha-din \\
& arranger law & arranger- & DEF-law \\
'lawyer' & \multicolumn{2}{c}{ 'the lawyer' }
\end{tabular}


(3) ISRAELI עורך דין

orekh din

arranger law

'lawyer'

\author{
העורך דין \\ ha-órekh din \\ DEF-arranger- law \\ 'the lawyer'
}

Analyticity in Israeli is also conspicuous in non-construct-state possession. Israeli favours a Yiddish analytic possessive construction, as in my grandfather, to a synthetic one. Thus, whereas the Hebrew phrase for 'my grandfather' was $s a v-i$ ' grandfather-1sgposs', in Israeli it is sába shel-i 'grandfather GEN-1 sg'.

But analyticity is not restricted to NPs. There are many non-Hebrew, periphrastic, complex verbal constructions in Israeli. Israeli sam tseaká 'shouted' literally means 'put a shout' (cf. the Hebrew-descent tsaák 'shouted'); natán mabát 'looked' literally means 'gave a look'; and heif mabát 'looked' literally means 'flew/threw a look' (cf., cast a glance, threw a look and tossed a glance) (cf. the Hebrew-descent hebit 'looked at'). The analytic grammatical construction (using auxiliary verbs followed by a noun) - employed here for the desire to express swift action - stems from Yiddish. Consider the following Yiddish expressions all meaning 'to have a look': gébn a kuk, lit. 'to give a look', ton a kuk, lit. 'to do a look' and the colloquial khapn a kuk, lit. 'to catch a look'.

Such constructions are not nonce, ad hoc lexical calques of Yiddish. The Israeli system is productive and the lexical realization often differs from that of Yiddish. Consider Israeli hirbits 'hit, beat; gave', which yielded hirbits mehirút 'drove very fast' (mehirút meaning 'speed'), hirbits arukhá 'ate a big meal' (arukhá meaning 'meal') — cf. English hit the buffet 'eat a lot at the buffet', hit the liquor/bottle 'drink alcohol'. Consider also Israeli dafák hofaá, lit. 'hit a show', i.e. 'dressed smartly'. This is not to say that the complex Semitic verbal forms were discarded (see $§ 2.3$ and $\S 2.4)$.

\subsection{Israeli as habere language: reinterpretation of a Hebrew form to fit a European pattern}

As opposed to Berman (1997: 329) and Ullendorff (1997: 558b), I argue that Israeli is a habere language (cf. Latin habere 'to have', taking the direct object), in stark contrast to Hebrew. How does one say in Israeli 'I have this book'? If one tried to speak 'proper Hebrew' (albeit with an Israeli accent, which is European), one would say the following:

(4) yésh

$\begin{array}{llll}\text { yésh } & \text { 1-i } & \text { ha-séfer } & \text { ha-zè } \\ \text { EXIS } & \text { DAT-1sg } & \text { DEF-book } & \text { DEF-msgPROX } \\ \text { there is } & \text { for me } & \text { the book } & \text { the this }\end{array}$

'I have this book'

The NP ha-séfer ha-zè is the subject of the sentence. However, in Israeli one would actually say the following:

(5) yésh

EXIS

there is

'I have this book' l-i et ha-séfer ha-zè

DAT-1sg ACC DEF-book DEF-msgPROX

for me ACC the book the this

Here, as demonstrated by the accusative marker et, the NP ha-séfer ha-zè is the direct object. That said, there are still normativists who 'correct' native Israeli-speakers and urge them only to use

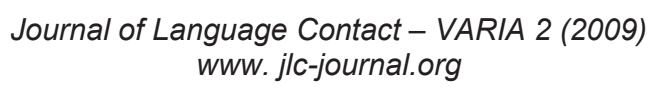


(4), which is, paradoxically, ungrammatical in most Israelis' idiolects. Ask these normativists how they say 'I have it'. None of them will actually utter *yesh $l-i h u$ 'EXIS DAT-1sg he'. Israeli for 'I have it' is yésh l-i ot-o ' "EXIS DAT-1sg ACC-he'. Consider also the Israeli expression yésh l-o et zè 'EXIS DAT-3msg ACC DEF-msgProX' ('he has this'), i.e. 'he is suitable/cool'. Again, it is impossible to say *yésh l-o ze 'EXIS DAT-3msg DEF-msgProx'.

Yiddish has two options to indicate possession. The most common form is (i)kh (h)ob, lit. 'I have', which requires a direct object (accusative). However, there is also a form which is more similar to old Hebrew: $b a(y)$ mir $i(z)$ do, lit. 'By me is there', followed by the subject (nominative) (Taube, 1984). The latter form, available in the feature pool together with the erstwhile non-habere Hebrew form, did not prevail because (i)kh (h) $o b$ is more productive in Yiddish-cf. other European habere languages.

In conclusion, the Hebrew existential construction employed to mark possession was reinterpreted in Israeli to fit in with a construction predominant in Yiddish and other European languages. A similar process occurred in Maltese: "in the possessive construction, subject properties have been transferred diachronically from the possessed noun phrase to the possessor, while the possessor has all the subject properties except the form of the verb agreement that it triggers" (Comrie, 1981: 212-218).

\subsection{Prosodic structure, verb-template productivity and the weak status of the consonantal root}

Traditional grammars of Hebrew describe seven verb-templates: $\triangle a \triangle a ́ \Delta, n i \triangle \triangle a ́ \Delta$ (its passive),

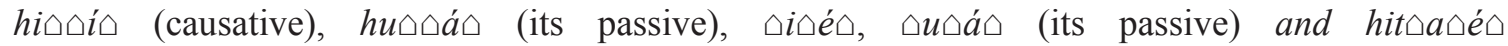
(reflexive/reciprocal/intransitive) (each $\triangle$ represents a slot, where a radical is inserted). Consider the following verbal morphemic adaptations in Israeli, all in the infinitive form (unless indicated otherwise):

A. Using the $h i \diamond(\triangle \diamond) \triangle i \triangle$ verb-template (historically transitive causative):

- le-hashvits (INTR) 'boast, show off', preserving the consonant cluster of its origin Yiddish shvits 'sweat'.

- le-hashprits (АMB) 'splash', retaining the consonant cluster of its origin Yiddish shprits (cf. German Spritz, spritzen) 'splash, spout, squirt' (Rubin, 1945: 306).

- le-haflik (AMB) 'slap', maintaining the consonant cluster of its onomatopoeic origin Yiddish flik 'pull, pluck' or Yiddish flok 'pole, club', cf. Israeli flik 'slap'.

- le-hasnif (АмВ) “"snort”, inhale (e.g. cocaine)', retaining the cluster of its origin English sniff (cf. snuff). The pre-existent Israeli snif 'branch' does not appear to play a role here.

B. Using the $\triangle a \triangle a ́ \triangle$ verb-template:

- la-khróp (INTR) 'sleep soundly, sleep tight', preserving the consonant cluster of its origin Yiddish khrópng 'to snore', cf. Yiddish khrop 'snore (n)'.

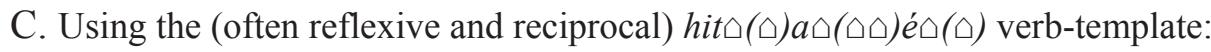

- The jocular slangism hitrandevú (INTR) '(they) had a rendezvous', preserving the cluster of its international source rendezvous (Sappan, 1971: 77a). 
D. Using the $(\Delta)(\Delta) \Delta i(\Delta)(\Delta) \triangle e ́ \Delta(\Delta)$ verb-template (traditionally $\triangle i \triangle e ́ \Delta)$ :

- le-katér (INTR) 'whine, complain', traceable to Polish Yiddish kútər 'male cat, complainer' (cf. Lithuanian Yiddish kótər) (perhaps because cats whine when asking for food / in heat / during copulation).

- le-fakés (TR) 'focus', traceable to the internationalism focus.

- le-faksés (TR) 'fax', traceable to the internationalism fax.

- le-flartét (INTR) 'flirt' (cf. flirtét 'flirt:3msgPaST'), reduplicating the [t] to preserve the cluster of the internationalism flirt.

- le-fargén (INTR) 'not begrudge', nativizing Yiddish fargínən 'not begrudge, not envy, indulge' (cf. the past participle form fargúnan), from German gönnen 'not to begrudge' or German vergönnen 'to grant'.

- le-daskés (АMB) 'discuss'.

- le-sankhrén (TR) 'synchronize' (The Academy of the Hebrew Language introduced the noun sinkrún 'synchronization'; see Laméd Leshonkhá 171, 1989).

- le-farmét (TR) 'format (in computing)'.

- le-tarpéd (TR) 'torpedo (figurative), sabotage'.

- le-sabséd (TR) 'subsidize'.

- le-natrél (TR) 'neutralize'.

- le-samés (AMB) 'to SMS'.

E. Using the $(\Delta) \triangle o \triangle \dot{e} \triangle$ variant of the $(\Delta)(\Delta) \triangle i(\Delta)(\Delta) \triangle \dot{e} \triangle(\Delta)$ verb-template:

- le-shnorér (TR) 'obtain by begging' (cf. the English slangism shnorr), from Yiddish shnórņ 'obtain by begging, sponge off, shnorr' (cf. Yiddish shnórər 'beggar, layabout, scrounger' and Israeli shnórer 'id.'). Israeli shnorér was introduced by Bialik in beir haharegá ('In the City of Slaughter', 1903; cf. 1959: 98b).

- le-yonén (TR) 'ionize', traceable to the internationalism ion.

- le-kodéd (TR) 'codify', from Israeli kod 'code', traceable to the internationalism code.

- le-otét (INTR) 'signal', an Israeli neologism based on the Hebrew-descent ot 'signal'.

Whereas $(\Delta)(\Delta) \Delta i(\Delta)(\Delta) \Delta \dot{\Delta} \Delta(\Delta)$ is productive, $\triangle a \triangle a \dot{\Delta}$ is not. The reason is due to what phonologists call 'prosodic structure'. The prosodic structure of $(\Delta)(\Delta) \Delta i(\Delta)(\Delta) \Delta e ́ \Delta(\Delta)$ (which I call $\sigma_{\mathrm{i}} \sigma_{\mathrm{e}}$, wherein $\sigma$ represents a syllable) is such that it retains consonant clusters throughout the tenses. Take, for example, le-transfér 'to transfer (people)' (TR). In the past (3msg) one says trinsfér, in the present metransfér and in the future yetransfér. The consonant clusters of transfer are kept throughout.

Let us try to fit transfer into $\triangle a \triangle a ́ \triangle$. The normal pattern can be seen in garám - gorém-yigróm 'cause:3msg (past, present, future)'. So, yesterday, he *transfär (3msgPAST) 'transferred (people)'; today, he *tronsfér. So far so good; the consonant clusters of transfer are maintained, the nature of the vowels being less important. However, the future form, *yitrnsfó $r$ is impossible because it violates Israeli phonology. As opposed to Hebrew $\mathrm{CV}(\mathrm{X})(\mathrm{C})$, the non-Semitic syllable structure of Israeli, $(\mathrm{s} / \mathrm{sh})(\mathrm{C})(\mathrm{C}) \mathrm{V}(\mathrm{C})(\mathrm{C})(\mathrm{s} / \mathrm{sh})$, facilitates morphemic adaptations of Yiddishisms, other Europeanisms, Americanisms and internationalisms. However, *yitrnsfó $r$ is impossible because any syllabification would violate the 'Sonority Sequencing Generalization', which in Israeli prohibits rising sonority from the peak to the margins. Thus, in Vtr.nsfV, for example, $r$ is more sonorous than $t$, and $n$ is more sonorous than $s$ and $f$. 
But even if *yitrnsfór were possible, it would still not be selected because-lacking a vowel between the $r$ and the $n$-it destroys the prosodic structure of transfer. This is exactly why click 'select by pressing one of the buttons on the computer mouse' is fitted into hi $\triangle(\Delta \Delta) \triangle i \Delta$ (hiklik)

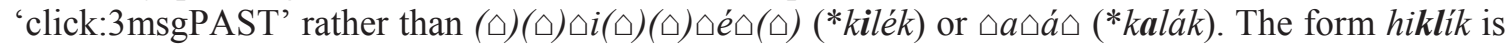
the only one which preserves the [kl] cluster. One important conclusion is that phonological

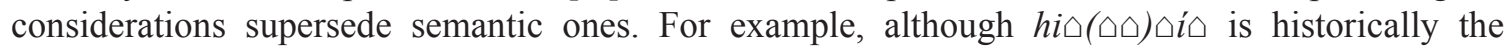
causative verb-template, it is employed - on purely phonological grounds - in the intransitive hishvits 'show off:3msgPAST' and in the ambitransitive (in fact, usually intransitive) hiklik 'click:3msgPAST'.

One crucial implication is the selected productivity of verb-templates. Unlike Hebrew, where the

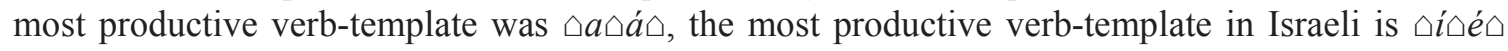
$\left(\sigma_{\mathrm{i}} \sigma_{\mathrm{e}}\right)$. This productivity is also apparent in the case of denominalizations (Bolozky, 1978; i.e. verbalizations) of nouns which are not perceived as foreign. Consider smirtét 'treat like a rag, render someone worthless (3msgPAST)', from smartút 'rag'; sibén 'soap, pull someone's leg (3msgPAST)', from sabón 'soap', and the above mentioned otét 'signaled', from the Hebrewdescent $o t$ 'signal'. Such denominalization in Israeli is far more productive than the occasional use

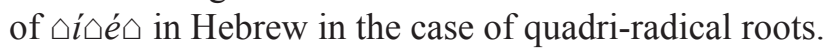

But there is another weighty conclusion: the uprooting of the importance of the Semitic consonantal root. Like Bat-El (1994, 2003), I argue that such verbs are based on a lexical item rather than on its alleged naturalized root within Israeli. As opposed to what Israelis are taught in intensive grammar lessons at primary and secondary schools, le-magnét 'to magnetize' (documented 1938, cf. Torczyner, 1938: 25) does not derive from the consonantal root m.g.n.ë fitted into the $\triangle i \Delta \dot{e} \triangle$ (in fact, $\sigma_{\mathrm{i}} \sigma_{\mathrm{e}}$ ) verb-template. Rather, it is traceable back to the internationalism magnet (Israeli magnét), which is the stem (or the root in the European sense) - rather than the root (in the Semitic, consonantal, sense) — of the verb.

Compared with the traditional Semitic consonantal root apophony, the system described here (e.g. hishprits 'splash:3msgPAST' - hishprátsti 'splash:1sgPAST') is much more similar to the Indo-European Ablaut ('vowel gradation') as in English sロng (sing-sang-song-sung) and German spr $\square$ ch (spricht-sprechen-sprach-gesprochen-Spruch). The consonantal root system-which does not play a role here - is a fundamental element of the morphology of Hebrew and other Semitic languages. Although, on the face of it, the forms used, viz. verb-templates, are Semitic, their

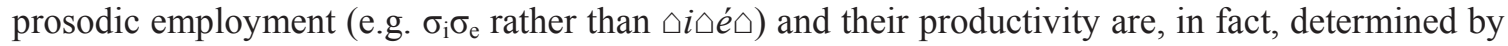
non-Semitic contributors.

\subsection{Inchoativity}

Yiddish has shaped the semantics of the Israeli verbal system. Consider the inchoative verbs, which denote the beginning of an action (an inceptive). While Israeli shakháv 'was lying down (3msg)' is neutral, Israeli nishkáv 'lay down, started being lain down (3msg)' is inchoative. Importantly, many Israeli inchoative forms are new and did not exist in Hebrew (Blanc, 1965: 1937). The verb-templates chosen to host these forms are the ones possessing prefixes: $\boldsymbol{n} \boldsymbol{i} \triangle \triangle \dot{a} \triangle$ and hit $\triangle a \triangle e ́ \triangle$. Table 1 contains examples of new inchoative verbs in Israeli and their Yiddish precursors, together with older neutral forms. (The translations of the Israeli verbs are in the present tense, although the basic form, which is presented here, is 3msgPast.)

My claim is not that the $\boldsymbol{n i} \triangle \triangle \dot{a} \triangle$ and hit $\triangle a \triangle \dot{e} \triangle$ verb-templates were chosen to host the inchoative forms because the Yiddish inchoative forms usually have a prefix (consider Yiddish avékleygn zikh 'lie down' and avékshteln zikh 'stand up', as opposed to the neutral Yiddish lígn 'be lying down'). Rather, since the non-inchoative forms are semantically unmarked, the verb-template hosting them is the unmarked $\triangle a \triangle a ́ \Delta$. Consequently, other verb-templates-which happen to include 'prefixes'- host the inchoative forms, thus making the inchoative aspect in Israeli 
systematic. Whilst Yiddish also indicates inchoativity by the use of the reflexive zikh or of vern 'become', Israeli opted to grammaticalize this notion using its existing system of verb-templates, in this case two intransitive verb-templates: passive $n i \triangle \triangle a ́ \Delta$ and reflexive, reciprocal hit $\triangle a \triangle e ́ \Delta$. In other words, Yiddish introduced a clear-cut semantic-grammatical distinction in Israeli between inchoative and non-inchoative, using the pre-existent inventory of Hebrew forms.

The Yiddish impact may also be seen in the presence of analytic (cf. §2.1) neutral (noninchoative) verbs which have developed - due to analogy - from inchoative forms, for example hayá malé 'was full (m)', hayá zakén 'was old (m)', and hayá nirgásh 'was excited (m)'. Note also that often the Yiddish contribution has resulted in the increased use of a pre-existent inchoative Hebrew form. Further research should examine - in line with the Congruence Principle and multiple causation - whether the Yiddish inchoative impact was amplified or accompanied by the co-existence of parallel inchoative forms in Russian and Polish, the latter two languages having been spoken by many first Israeli speakers (cf. §2.12). 
Table 1 : Inchoative verbs in Yiddish and in Israeli

\begin{tabular}{|c|c|c|c|c|}
\hline \multicolumn{2}{|c|}{$\begin{array}{c}\text { NEUTRAL } \\
\text { (DURATIVE) (unmarked) }\end{array}$} & \multicolumn{3}{|c|}{$\begin{array}{c}\text { INCHOATIVE } \\
\text { (DENOTING THE BEGINNING OF AN ACTION) (marked) }\end{array}$} \\
\hline $\begin{array}{c}\text { Israeli } \\
- \text {-Mostly Old Forms- }\end{array}$ & \multirow[t]{2}{*}{ Yiddish } & \multicolumn{2}{|c|}{$\begin{array}{c}\text { Israeli } \\
- \text { Mostly New Forms-- }\end{array}$} & \multirow[t]{2}{*}{ Yiddish } \\
\hline $\begin{array}{c}\triangle a \triangle a ́ \triangle \\
\text { Verb-Template }\end{array}$ & & $\begin{array}{c}n \boldsymbol{n i} \triangle \triangle \dot{a} \triangle \\
\text { Verb-Template }\end{array}$ & $\begin{array}{c}\text { hit } \triangle a \triangle e ́ \triangle \\
\text { Verb-Template }\end{array}$ & \\
\hline $\begin{array}{l}\text { שכב shakháv } \\
\text { 'be lying down' }\end{array}$ & lign ליגן lign & $\begin{array}{l}\text { 'lie down' } \\
\text { 'lisháv }\end{array}$ & & 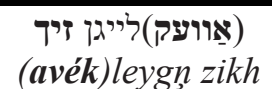 \\
\hline $\begin{array}{l}\text { עמ amád } \\
\text { 'be standing' }\end{array}$ & | שטיין shteyn & $\begin{array}{l}\text { Theemád } \\
\text { 'stand up' }\end{array}$ & & 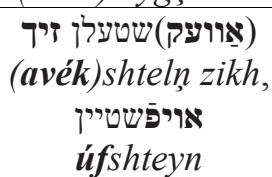 \\
\hline $\begin{array}{l}\text { עamád } \\
\text { 'be halted' }\end{array}$ & | שטיין shteyn & $\begin{array}{l}\text { עy neemád } \\
\text { 'come to a halt', }\end{array}$ & & 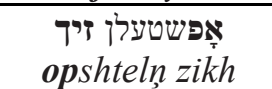 \\
\hline $\begin{array}{l}\text { זכakhár } \\
\text { 'remember' }\end{array}$ & $\begin{array}{l}\text { געדענקען } \\
\text { gedénkon }\end{array}$ & $\begin{array}{c}\text { 'זכוzkár } \\
\text { 'recall, remember } \\
\text { suddenly' }\end{array}$ & & 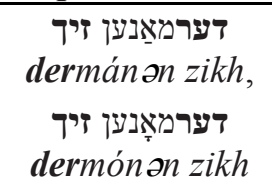 \\
\hline $\begin{array}{l}\text { פ פ pakhád } \\
\text { 'be afraid' }\end{array}$ & 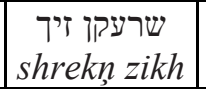 & $\begin{array}{c}\text { פבהל nivhál } \\
\text { 'become frightened' }\end{array}$ & & $\begin{array}{c}\text { דע:רשרעקן זיד } \\
\text { dershrékņ zikh }\end{array}$ \\
\hline $\begin{array}{c}\text { היה hayá } \\
\text { 'be' }\end{array}$ & זיון zayn & $\begin{array}{c}\text { פהi(hi)yá } \\
\text { 'become' }\end{array}$ & & $\begin{array}{l}\text { ווערן } \\
\text { vern }\end{array}$ \\
\hline $\begin{array}{l}\text { 'yashán } \\
\text { 'sleep' }\end{array}$ & שלאָפן shlófng | & $\begin{array}{l}\text { 'Aרirdám } \\
\text { 'fall asleep' }\end{array}$ & & 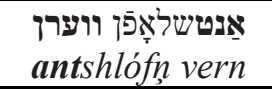 \\
\hline $\begin{array}{l}\text { היה רגוע hayá ragúa } \\
\text { 'be calm' }\end{array}$ & & $\begin{array}{l}\text { 'calm down' } \text { ' nirgá } \\
\text { 'calm }\end{array}$ & & \\
\hline $\begin{array}{l}\text { ' yasháv } \\
\text { 'be sitting' }\end{array}$ & זיצן zitsņ & & $\begin{array}{c}\text { התישב hityashév } \\
\text { 'sit down' }\end{array}$ & 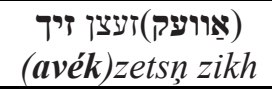 \\
\hline $\begin{array}{l}\text { שת shaták } \\
\text { 'be silent' }\end{array}$ & $\begin{array}{c}\text { שוובגיגן } \\
\text { shváygn }\end{array}$ & & $\begin{array}{l}\text { השתת hishtaték } \\
\text { 'become silent' }\end{array}$ & 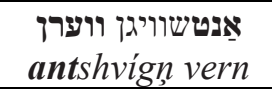 \\
\hline אהב aháv 'love' & $\begin{array}{l}\text { ליב האָבן } \\
\text { líb hobngn }\end{array}$ & & $\begin{array}{l}\text { התאהב hitahév } \\
\text { 'fall in love' }\end{array}$ & 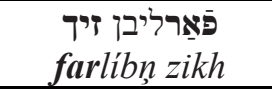 \\
\hline $\begin{array}{c}\text { בל balát } \\
\text { 'be prominent' }\end{array}$ & & & $\begin{array}{c}\text { התבלט hitbalét } \\
\text { 'become prominent' }\end{array}$ & \\
\hline $\begin{array}{c}\text { שלט shalát } \\
\text { 'control' }\end{array}$ & & & $\begin{array}{c}\text { השתלט hishtalét } \\
\text { 'get control' }\end{array}$ & \\
\hline $\begin{array}{c}\text { היה משו' hayá nasúy } \\
\text { 'be married' }\end{array}$ & & & $\begin{array}{l}\text { התחתן hitkhatén } \\
\text { 'get married' }\end{array}$ & \\
\hline $\begin{array}{c}\text { היה מלא hayá malé } \\
\text { 'be full' }\end{array}$ & & & $\begin{array}{c}\text { התמלא hitmalé } \\
\text { (hitmalá) 'get full' }\end{array}$ & \\
\hline $\begin{array}{c}\text { היה זקן hayá zakén } \\
\text { 'be old' }\end{array}$ & & & $\begin{array}{c}\text { הזדקן hizdakén } \\
\text { 'become old' }\end{array}$ & \\
\hline $\begin{array}{c}\text { היה נרגש hayá nirgásh } \\
\text { 'be excited' }\end{array}$ & & & $\begin{array}{c}\text { 'get excited' } \\
\text { 'gitragésh }\end{array}$ & \\
\hline
\end{tabular}




\subsection{Decliticization-in-progress of the proclitics be- 'in', le- 'to', mi-/me- 'from', ve- 'and'}

Following Standard Average European, the Israeli proclitics be- 'in', le- 'to' and mi-/me 'from', as well as the coordinating conjunction ve- 'and', are phonologically less dependent than in Hebrew. Although orthographically be- 'in', le- 'to' and $m i-/ m e$ 'from'- as well as the ve- 'and'form one orthographic word with the following host, there are several manifestations of decliticization-in-progress:

(I) In Hebrew, the scope of the proclitic was limited to one host: one would have to say be-'atúna, be-zhenéva u-ve-lóndon (<ve-be-lóndon), lit. 'in Athens, in Geneva and in London'. In Israeli-just like in English—one says be-atúna, zhenéva ve-lóndon, lit. 'in Athens, Geneva and London'.

(II) An Israeli can pause after these prepositions, and insert a host which s/he did not have in mind before pronouncing the preposition. For example, one can say ze hayá be, be-mélborn, lo, sídni 'It was in, in Melbourne, no, Sydney'.

(III) Unlike in Hebrew, there is no spirantization of a following [b], [k] and [p] (into $[\mathrm{v}],[\chi]$ and $[\mathrm{f}]$ ). For example, Israeli 'in-grade second' (i.e. 'in the second grade') is be-kitá bet rather than be-khitá bet.

(IV) Unlike in Hebrew, the proclitic does not change its vowel according to the first syllable of the host. For example, in Israeli one says be-shvédya 'in-Sweden' rather than bi-shvédya.

Thus, although the forms used are Hebrew prepositions, they are restructured to replicate the European/Yiddish pattern. This clitic weakening may result in full decliticization.

\subsection{Numeral and noun (dis)agreement}

Hebrew had a consistent polarity-of-gender agreement between nouns and numerals. Consider 'éser banót 'ten girls' versus 'asar-á baním 'ten-fsg boys'. In the latter, the feminine suffix $-a$ is added to the numeral which modifies a masculine noun. (Israeli pupils are told that asar-a is masculine but this is historically incorrect; the $-a$ suffix stands for feminine; see Israeli ashir 'rich (m)' versus ashir-á 'rich (f)') However, in most Israeli idiolects, sociolects and dialects, the system is much simpler: éser banót 'ten girls' and éser banim 'ten boys'. Just like in Yiddish, there is no difference between a numeral modifying a masculine noun and a numeral modifying a feminine one.

That said, although $90 \%$ of Israelis (Ravid, 1995) do not follow the polarity-of-gender agreement (some of them say asar-á shkal-im, lit. 'ten-feminine.singular shekel-masculine.plural', i.e. 'ten shekels', but 'fail' in many other instances), there are some Israelis who speak a variety in which asar-á shkal-im is indeed the grammatical form. These speakers are cherished by the Academy of the Hebrew Language. In fact, massive normative pressure (Zuckermann, 2008b) has resulted in hypercorrect conflated forms. Official rules are often used inconsistently because they are-paradoxically - counter-grammatical vis-à-vis numerous idiolectal, sociolectal or dialectal realities For example, there are speakers who say—normatively—shlosh-á shkal-ím 'three shekels' (cf. the non-prescriptive shalósh shékel) but shlósh-et ha-dód-ot 'the three aunts' (cf. the normative shlósh ha-dod-ót).

Thus, Israeli already shows signs of diglossia: native Israeli speech versus non-native (highflown, pseudo-) Hebrew in writing. If language planning persists, that is if Israeli teachers continue to indoctrinate Israelis to use Hebrew (e.g. 'asar-á baním to name but one example out of

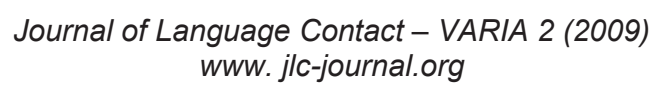


hundreds) - rather than Israeli (e.g. éser baním) — grammar, full diglossia may be established—cf. mutatis mutandis Arabic polyglossia: Modern Standard Arabic (cf. Classical Arabic)—as opposed to the various vernacular Arabics (cf. so-called Arabic dialects) - is no-one's mother tongue. Most Arabs consider Modern Standard Arabic as their language and yet speak Palestinian Arabic or Egyptian Arabic and so forth.

\subsection{Tense system}

As opposed to Biblical Hebrew, which had no tenses, only a perfect/imperfect distinction, Israeli-like Yiddish and Mishnaic Hebrew-has instead three tenses: past, present and future. The problem here warrants solutions similar to those in $\$ 2.8$ (see below). I would like to suggest that the Israeli tense system is multi-parental.

Note that in the past and future, verbal forms differ according to gender, number and person. However, in the present tense, verbs are only conjugated according to gender and number and there is no person distinction. The reason is that the forms of the Israeli present can be traced back to the Hebrew participle, which is less complex than the historical perfect and imperfect forms.

\subsection{Constituent order}

Israeli linguists often claim that Israeli constituent order, $\mathrm{AVO}(\mathrm{E}) / \mathrm{SV}(\mathrm{E})$, demonstrates the impact of Mishnaic Hebrew, which had it as the marked order (for emphasis/contrast) - as opposed to Biblical Hebrew, usually characterized by $\mathrm{VAO}(\mathrm{E}) / \mathrm{VS}(\mathrm{E})$ order. However, there is resemblance between Mishnaic Hebrew and Standard Average European syntax. There are various possible analyses or interpretations, including the following:

(i) One source: Israeli constituent order is Hebrew and serendipitously resembles that of SAE. After all, there is a limited number of options.

(ii) One source: Israeli constituent order is SAE and serendipitously resembles that of erstwhile Mishnaic Hebrew (or a more recent literary variant of Hebrew).

(iii) Multiple source: Israeli constituent order is simultaneously based on SAE and Hebrew.

Whereas normativists opt for Analysis (i), revisionists prefer Analysis (ii). They are actually similar in that they both believe in one source. My hybridizational model, which has multiple causation at its core, would advocate Analysis (iii).

\subsection{Copula enhancement}

Unlike Hebrew, which has a plethora of verbless sentences, Israeli often uses copulas, viz. the proximal demonstrative $z e$ and the pronouns $h u$ 'he', $h i$ 'she', hem 'they (m)' and hen 'they (f)', all

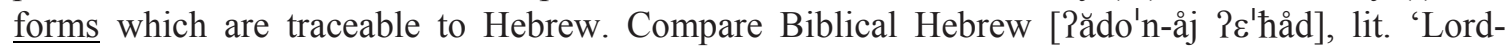
pl:1sgposs one', i.e. 'Our Lord is one' (Deuteronomy 6:4), with Israeli késef ze lo ha-kól, lit. 'money COP NEG DET-all', i.e. 'Money is not everything'. Israeli does not accept *késef lo hakól. Whereas the copula existed in Hebrew, its use was reinforced by Yiddish and other European languages. In verbless sentences Yiddish always has a copula: dos méydl iz klug 'The girl is clever'. Again, although the patterns employed here are European, the forms are still Hebrew.

\subsection{Phono-semantic matching}

Israeli has more than 200 'phono-semantic matches' (PSM, Zuckermann, 2003), in which a lexical item derives simultaneously from two (or more) sources which are (usually serendipitously) phonetically and semantically similar. I define PSM as camouflaged borrowing in which a foreign 
lexical item is matched with a phonetically and semantically similar pre-existent native word/root. For example:

(6)

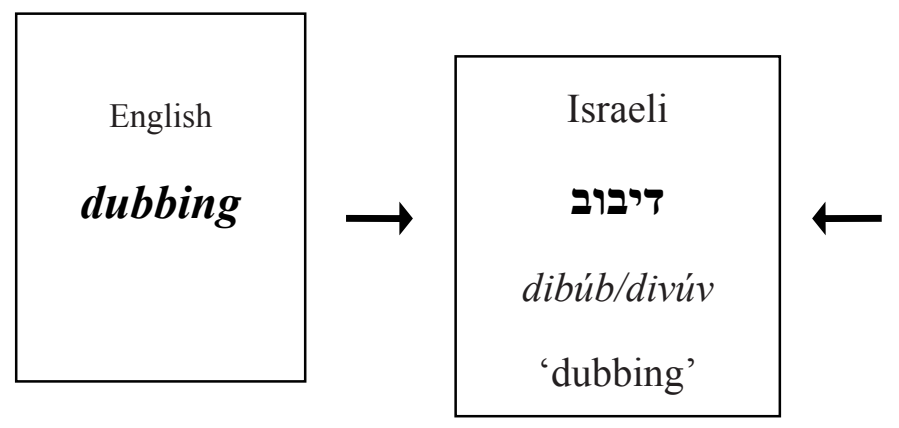

(Medieval) Hebrew

$$
\text { דבוב }
$$

dibbú $\underline{\underline{b}}$

'speech', 'inducing someone to speak'

cf. דובב שפתי ישנים 'causing the lips of those that are asleep to speak' in Song of Solomon 7:10

(7)

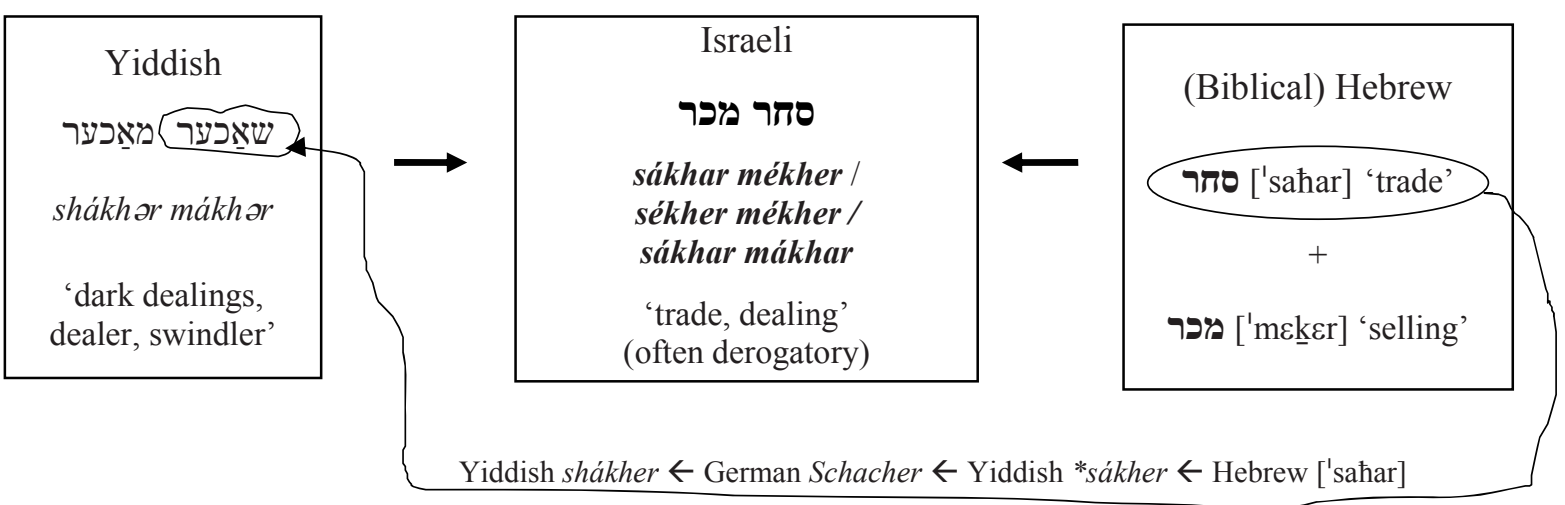

Often in PSM, the source-language not only dictates the choice of root, but also the choice of noun-pattern, thus constituting a camouflaged influence on the target-language morphology. For example, the phono-semantic matcher of English dock with Israeli מבזקוק mivdók could have usedafter deliberately choosing the phonetically and semantically suitable root בדק $\sqrt{ } b d q$ 'check' (Rabbinic), 'repair' (Biblical) - the noun-patterns mi $\triangle \Delta a \triangle a ́, m a \triangle \Delta e \triangle a ́$, mi $\triangle \triangle e ́ \triangle e t$, mi $\triangle \triangle a \triangle a ́ i m$ etc. (each $\triangle$ represents a slot where a radical is inserted). Instead, mi $\triangle \Delta \dot{\Delta} \Delta$, which was not highly productive, was chosen because its [o] makes the final syllable of מבדוק mivdók sound like English dock.

As opposed to almost all other features discussed in this article, such 'lexical accommodations' (Dimmendaal, 2001: 363) are frequently concocted by language planners as a means of camouflaged borrowing. Consider the following examples: 
(8)

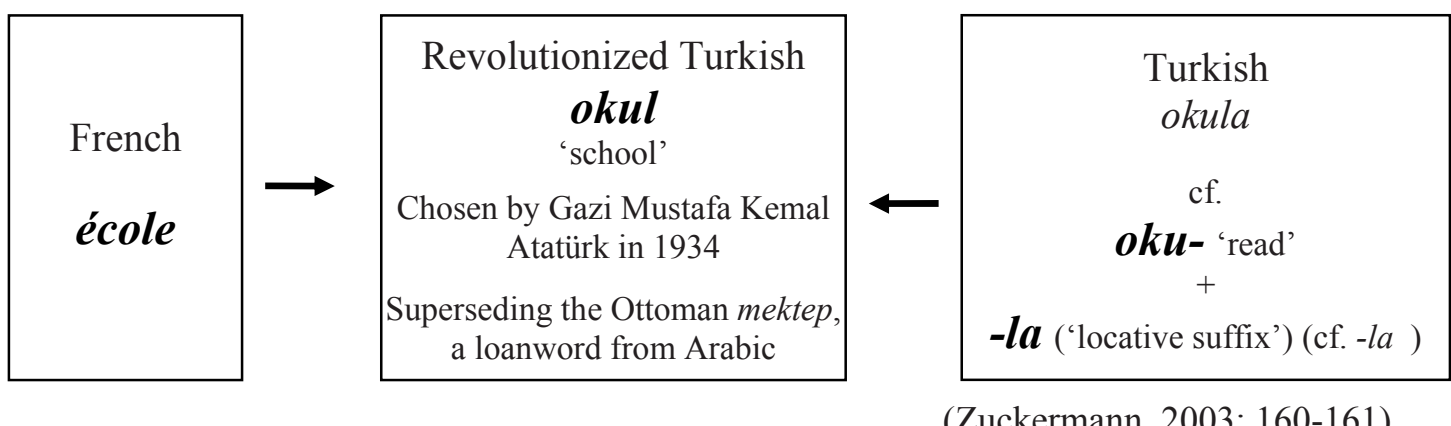

(9)

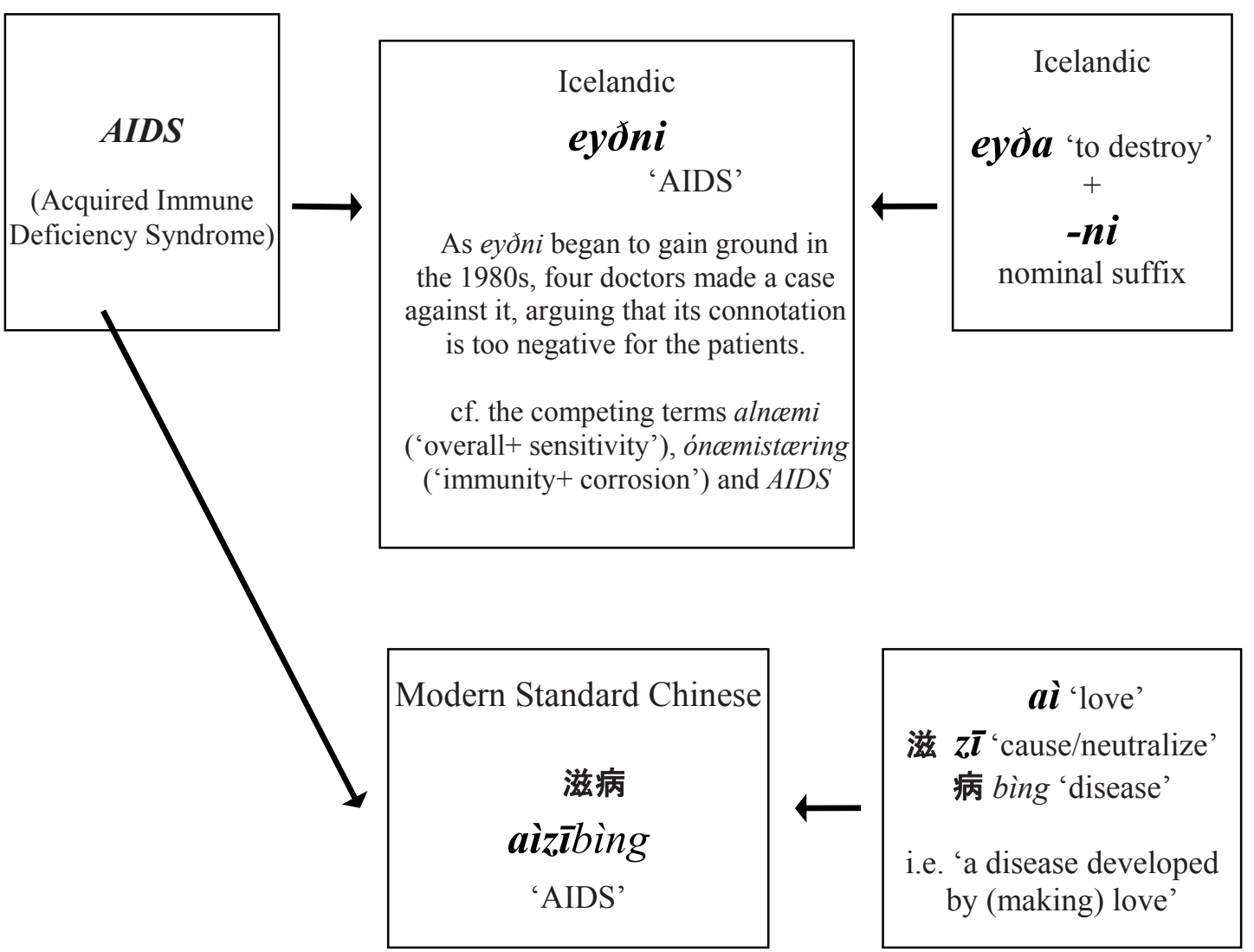

(Sapir \& Zuckermann, 2008)

But structurally similar concoctions - albeit usually spontaneous - are also created by laymen (resembling 'lexical conflations' in creoles, Zuckermann, 2003):

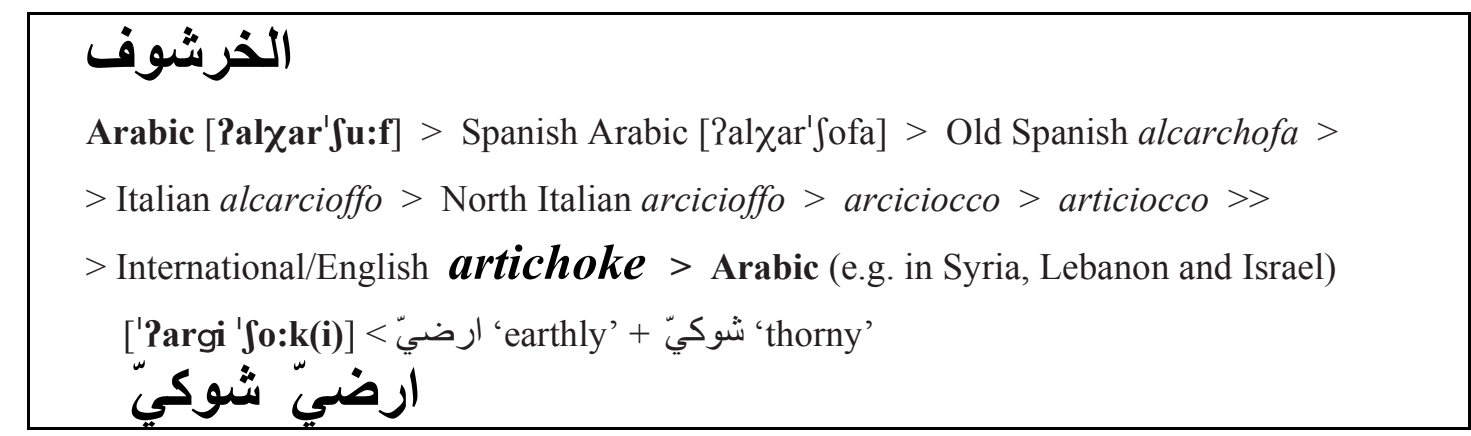




\subsection{Linguistic gender and noun-template productivity}

Morphemic adaptations of English words into American Italian or British Italian often carry the linguistic gender of the semantically-similar word in Italian itself, e.g. British Italian bagga 'bag' (f), induced by Italian borsa 'id.' (f). Israeli, which has numerous possible noun-templates, demonstrates the same phenomenon (and it is still to be determined how regular the pattern of such gender adaptations is). Consider Israeli mivréshet 'brush' and Israeli mis 'éret '(originally) brush, (later) soft brush with long bristles', both feminine. I suggest that the choice of the feminine nountemplate $m i \triangle \triangle e ́ \Delta e t$ (each $\triangle$ represents a slot where a radical is inserted) was engendered by the (feminine) gender of the following words for 'brush'. Table 2 illustrates brush in Israeli and in its various contributing languages:

Table 2 : The gender of brush in Israeli and in its various contributing languages

\begin{tabular}{|c|c|c|c|c|c|c|c|}
\hline Israeli & Arabic & English & Yiddish & Russian & Polish & German & French \\
\hline $\begin{array}{c}\text { mivréshet } \\
\text { (f) }\end{array}$ & $\begin{array}{c}\text { mábrasha } \\
\text { (f) }\end{array}$ & brush & $\begin{array}{c}\text { barsht } \\
\text { (f) }\end{array}$ & $\begin{array}{c}\text { shchétka (f); } \\
\text { kist' (f) 'painting } \\
\text { brush' }\end{array}$ & $\begin{array}{c}\text { szczotka } \\
\text { (f) }\end{array}$ & $\begin{array}{c}\text { Bürste } \\
\text { (f) }\end{array}$ & $\begin{array}{c}\text { brosse } \\
\text { (f) }\end{array}$ \\
\hline
\end{tabular}

Note that although mi $\triangle \Delta e ́ \Delta e t$ is indeed used for instruments, there were many other possible suitable noun-templates, cf. *mavrésh and *mivrásh, both masculine. One might argue that the

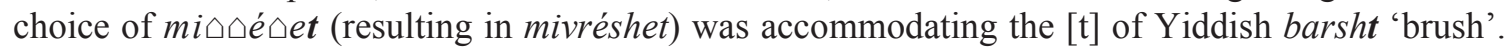
This does not weaken the hypothesis that the gender played a crucial role, since Ben-Yehuda's original form of this coinage was Israeli mivrashá, fitted into the mi $\triangle a \triangle a ́$ noun-template, the latter lacking [t] but still feminine. Israeli mivréshet, which might have sounded more elegant to the emerging native speakers, came later.

Similarly, Israeli sifriá 'library' was preferred to the construct-state (N-N) bet sfar-im, lit. 'house- books'. Some intra-Israeli reasons could have been the wish to (i) streamline the word for convenience (one word being preferred to two words); (ii) prevent a possible confusion with bet séfer, lit. 'house- book', denoting 'school'; and (iii) follow the more general Israeli analyticity $(\S 2.1)$.

However, there was also a camouflaged external reason: sifriá is feminine, thus maintaining the gender of the parallel European words: Yiddish biblioték, Russian bibliotéka, Polish biblioteka, German Bibliothek and French bibliothèque. Perhaps the feminine gender of Arabic máktaba 'library' played a role as well. One might say that this camouflaged foreign influence is only lexical. However, one result of this neologism might have been, more generally, the strengthening of Israeli -iá as a productive feminine locative suffix.

Future research should systematically explore the gender of all Israeli coinages vis-à-vis their counterparts in European and Semitic languages which have contributed to Israeli. Zuckermann (2003) has already done so with regard to several hundreds phono-semantic matches. 


\subsection{Calquing}

Consider the following greeting:

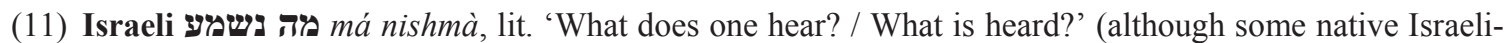
speakers understand it as the homophonous 'What shall we hear?'), i.e. 'How are you?', 'What's up?'

$<$

(1) Yואזס הערט זיך vos hert zikh (usually pronounced v(o)sértsəkh), lit. 'What does one hear?', i.e. 'How are you?', 'What's up?'

(2) Russian Что слышно chto slýshno 'id.'

(3) Polish Co stychać 'id.'

(4) Romanian Ce se aude 'id.'

Note that whereas most revivalists were native Yiddish-speakers, many first speakers of Israeli spoke Russian and Polish too. So a Polish speaker in the 1930s might have used má nishmà not (only) due to Yiddish vos hert zikh but rather (also) due to Polish Co słychać and so forth. That is a manifestation of the Congruence Principle.

Israelis know that the Israeli word perestroika is a borrowing of the Russian-descent internationalism. However, few Israelis are aware that the common Israeli greeting má nishmà? is actually a calque. Synchronically speaking, the forms in this phrase are $100 \%$ Hebrew, there is nothing to betray the non-Hebrew co-sources (Yiddish, Polish, Russian), which provided the pattern (cf. calques in Howell, 1993). It is no wonder, then, that so many people miss much of the European impact on Israeli.

\subsection{Portmanteau blending}

Word-formation in Israeli abounds with European mechanisms such as blending. Along with kómpaktdisk 'compact disc', Israeli has the blend taklitór, which consists of the Hebrew-descent taklit 'record' and 'or 'light'. Unlike Hebrew, Israeli is full of portmanteau blends (cf. motel < motor+hotel) such as (1) arpíakh 'smog', from arafél 'fog' and piakh 'soot'; (2) mídrakhov '(pedestrian) mall, promenade', from midrakhá 'pavement, sidewalk' and rekhóv 'street'; (3) makhazémer 'musical', from makhazé 'play (n)' and zémer 'singing'; or (4) bohoráim 'brunch', from bóker 'morning, breakfast (cf. arukhát bóker 'breakfast')' and tsohoráim 'noon, lunch (cf. arukhát tsohoráim 'lunch')'.

Furthermore, Israeli has cases of root blending, e.g. (1) dakhpór 'bulldozer', which hybridizes

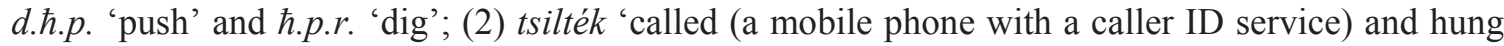
up, expecting a return call' (e.g. a boy calling his mother, the latter having a cheaper calling plan), from tsiltsél 'called, phoned' and niték 'hung up'; (3) most recently khipsés 'looked for a phone number by sending an SMS to an operator', from khipés 'looked for' and simés 'sent an SMS'; (4) shiltút 'zapping, flipping through the channels' (cf. shiltét 'zapped'), which derives from shalát '(remote) control' and shitút 'wandering, vagrancy'.

\section{Conclusions}

This article contributes towards recognizing that the revival of a no-longer spoken language is unlikely without cross-fertilization from the revivalists' mother tongue(s) and towards understanding Israeli as a hybridic language. In Israeli the impact of Yiddish and other European languages is apparent in all the components of the language but usually in patterns rather than in forms. Moreover, Israeli demonstrates a split between morphology and phonology. Whereas most Israeli morphological forms, e.g. discontinuously-conjugated verbs, are Hebrew, the phonetics and 
phonology of Israeli-including the pronunciation of these Hebrew forms-are European (Zuckermann, 2005).

Future research should examine each linguistic feature of Israeli individually vis-à-vis Hebrew, Yiddish and all the other contributing languages. The grammatical contact in the emergent language was too complex to fit sweeping models such as 'revival of Hebrew', 'relexification of Yiddish by Hebrew', or universalist simplification. Such en bloc explanations overlook valuable statistics of each grammatical feature in the feature pool, e.g. how many contributors happened to possess it.

I hypothesize that the Congruence Principle is most significant to the study of Israeli: If a feature exists in more than one contributing language (or idiolect, sociolect, ethnolect etc.), it is more likely to persist in the emerging language. This principle is applicable to all languages, and indeed to linguistic evolution in general. It is of particular importance, however, to new languages, i.e. to linguistic genesis.

Thus, there are numerous conclusions one could draw from Israeli about language in general for the following reasons: (i) The impact of-and preferences in-language engineering share similarities with more natural processes of contact-induced change; (ii) The role of the European languages in Israeli was not deliberate, i.e. there are many aspects in Israeli which can be regarded as 'natural'. The case of Israeli demonstrates that the reality of linguistic genesis is far more complex than a simple family tree system allows. 'Revived' languages are unlikely to have a single parent.

The Hebrew revivalists' attempt to deny their European roots, negate diasporism and avoid hybridity (as, in fact, reflected in Yiddish itself, which most revivalists despised) failed. Thus, the study of Israeli offers a perspicacious insight into the dynamics between language and culture in general, and in particular into the role of language as a source of collective self-perception. I maintain that Israeli is a Eurasian (Semito-European) hybrid language: both Afro-Asiatic and IndoEuropean. Whatever we choose to call it, we should acknowledge its complexity. When one revives a language, one should expect to end up with a hybrid.

\section{References}

Bachi, Roberto. 1956. tkhiyát halashón haivrít beaspaklárya statístit (The Revival of the Hebrew Language from a Statistical Perspective). Lešonénu 20 (1): 65-82.

Bachi, Roberto. 1977. The Population of Israel. Jerusalem: Institute of Contemporary Jewry, Hebrew University of Jerusalem - Demographic Center to the Prime-Minister's Office in Israel.

Bat-El, Outi. 1994. Stem Modification and Cluster Transfer in Modern Hebrew. Natural Language and Linguistic Theory 12: 571-96.

Bat-El, Outi. 2003. Semitic Verb Structure within a Universal Perspective. In: Joseph Shimron (ed.). Language Processing and Acquisition in Languages of Semitic, Root-based, Morphology, 29-59. Amsterdam: John Benjamins.

Berman, Ruth A. 1997. 'Modern Hebrew'. N: Robert Hetzron (ed.). The Semitic Languages, 31233. London: Routledge.

Bernini, Giuliano \& Paolo Ramat. 1996. Negative Sentences in the Languages of Europe: A Typological Approach (Empirical Approaches to Language Typology 16). Berlin: Mouton de Gruyter.

Bialik, Chaim Nachman. 1959. kol kitvéy byálik (The Complete Works of Bialik). Tel Aviv: Dvir.

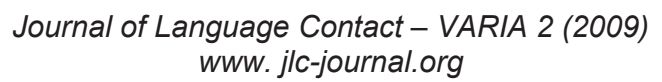


Blanc, Haim. 1965. Yiddish Influences in Israeli Hebrew. In: Uriel Weinreich (ed.). The Field of Yiddish: Studies in Language, Folklore and Literature (Second Collection), 185-201. The Hague: Mouton.

Bolozky, Shmuel. 1978. Word Formation Strategies in Hebrew Verb System: Denominative Verbs, Afroasiatic Linguistics 5: 1-26.

Chomsky, William (Zev). 1957. Hebrew - The Eternal Language. Philadelphia: The Jewish Publication Society of America.

Chomsky, William (Zev). 1967. halashón haivrit (The Hebrew Language). Jerusalem. (An expansion and translation of Hebrew - The Eternal Language, 1957).

Comrie, Bernard. 1981. Language Universals and Linguistic Typology. Syntax and Morphology. Oxford: Basil Blackwell.

Dawkins, Richard MacGillivray (1916). Modern Greek in Asia Minor: A Study of the Dialects of Silli, Cappadocia and Phárasa with Grammar, Texts, Translations and Glossary. Cambridge: Cambridge University Press.

Dimmendaal, Gerrit J. 2001. Areal Diffusion versus Genetic Inheritance: An African Perspective. In: Alexandra Y. Aikhenvald \& Robert M. W. Dixon (eds.), 358-92. Areal Diffusion and Genetic Inheritance. Problems in Comparative Linguistics. Oxford: Oxford University Press.

Dorian, Nancy. 1993. Internally and Externally Motivated Change in Language Contact Settings: Doubts about the Dichotomy. In: Charles Jones (ed.), 131-155. Historical Linguistics: Problems and Perspectives, London: Longman.

Glinert, Eliezer (Lewis). 1991. 'lemekór haivrít hakhadashá hamedubéret: iyuním batakhbír hasamúy shel 'lefí hatáf' ledavíd yélin' (On the Source of Spoken Modern Hebrew: Studies of the Covert Syntax in Lefi Hatáf by David Yellin). Leshonenu 55: 107-26.

Goldenberg, Gideon. 1996. 'haivrít kelashón shémit khayá' (Hebrew as a Living Semitic Language). In: Joshua Blau (ed.), 148-90. halashón haivrit behitpatkhutá uvehitkhadshutá (Evolution and Renewal: Trends in the Development of the Hebrew Language). Jerusalem: Israel Academy of Sciences and Humanities.

Haig, Geoffrey. 2001. Linguistic Diffusion in Present-Day East Anatolia: From Top to Bottom. In: Alexandra Y. Aikhenvald \& Robert M. W. Dixon (eds.), 195-24. Areal Diffusion and Genetic Inheritance. Problems in Comparative Linguistics. Oxford: Oxford University Press.

Haramati, Shlomo. 1992. ivrit khayá bimrutsát hadorót (Living Hebrew throughout the Generations). Israel: Masada.

Haramati, Shlomo. 2000. ivrit safá medubéret (Hebrew - A Spoken Language). Israel: Ministry of Defence.

Harrison, Geoffrey A., J. M. Tanner, D. R. Pillbeam \& P. T. Baker. 1988. Human Biology: An Introduction to Human Evolution, Variation, Growth, and Adaptability. Oxford: Oxford University Press.

Haspelmath, Martin. 1998. How Young is Standard Average European?. Language Sciences 20: 271-87.

Haspelmath, Martin. 2001. The European Linguistic Area: Standard Average European. In: Martin Haspelmath, Ekkehard König, Wulf Oesterreicher \& W. Raible (eds.), 1492-510. Language 
Typology and Language Universals: An International Handbook, Vol. 2. Berlin: Walter de Gruyter.

Hjelmslev, Louis. 1938. Etudes sur la notion de parenté linguistique. Revue des Etudes IndoEuropéennes 1: 271-86.

Horvath, Julia \& Paul Wexler. 1997. (eds.) Relexification in Creole and Non-Creole Languages With Special Attention to Haitian Creole, Modern Hebrew, Romani, and Rumanian. Wiesbaden: Harrassowitz.

Howell, Robert B. 1993. German Immigration and the Development of Regional Variants of American English: Using Contact Theory to Discover Our Roots. In: Joseph Salmons (ed.), 190-212. The German Language in America, Madison: Max Kade Institute.

Kerswill, Paul. 2002. Koineization and Accommodation. In: J.K. Chambers, Peter Trudgill \& Natalie Schilling-Estes (eds.), 669-702. The Handbook of Language Variation and Change. Oxford: Blackwell.

Kuteva, Tania. 1998. Large Linguistic Areas in Grammaticalization: Auxiliation in Europe. Language Sciences 20: 289-311.

Laméd Leshonkhá (Teach Your Language) 1951-90 (Leaflets 1-180). A. Dotan (ed.: Leaflets 1-8), Sh. Bahat (ed.: Leaflets 9-180). Jerusalem: Academy of the Hebrew Language.

Lewis, Geoffrey L. 1967. Turkish Grammar. Oxford: Oxford University Press.

McWhorter, John H. 2002. What happened to English? Diachronica 19.217-272.

Maschler, Yael. 1994. Metalanguaging and Discourse Markers in Bilingual Conversation, Language in Society 23: 325-66.

Maschler, Yael. 2003. The Discourse Marker nu: Israeli Hebrew Impatience in Interaction, Text 23: $89-128$.

Muchnik, Malka. 2004. Is Modern Hebrew a Synthetic or Analytic Language? Suffixes and Independent Pronouns in the Writing of Haim Be'er. Folia Linguistica XXXVIII: 257-76.

Mufwene, Salikoko S. 2001. The Ecology of Language Evolution. Cambridge: Cambridge University Press.

Rabin, Chaim. 1974. 'halashón haivrít bat yaménu' (Contemporary Hebrew). In: haentsiklopédya haivrit (Hebrew Encyclopedia), Vol. xxvi, 660-4.

Rabin, Chaim 1981. ikaréy toldót halashón haivrit (The Main History of the Hebrew Language). Jerusalem: HaMakhlaka leKhinukh uleTarbut baGola shel haHistadrut Hatsionit haOlamit. (5th Reprint).

Ravid, Dorit. 1995. Neutralization of Gender Distinction in Modern Hebrew Numerals. Language Variation and Change 7: 79-100.

Rubin, Israel. 1945. 'végņ der vírkung fun yídish áfṇ gerédtñ hebréish in érets yisróel' (On the Effect of Yiddish on Spoken Hebrew in Eretz Yisrael). Yivo Bleter (Journal of the Yiddish Scientific Institute) xxv: 303-9.

Sapir, Yair \& Ghil'ad Zuckermann. 2008. Icelandic: Phonosemantic Matching. In: Judith Rosenhouse \& Rotem Kowner (eds.), 19-43 (Chapter 2). Globally Speaking: Motives for Adopting English Vocabulary in Other Languages. Clevedon - Buffalo - Toronto: Multilingual Matters.

$$
\begin{gathered}
\text { Journal of Language Contact - VARIA } 2 \text { (2009) } \\
\text { www. jlc-journal.org }
\end{gathered}
$$


Sappan, Raphael. 1971. milón hasléng haisraeli (Dictionary of Israeli Slang). Jerusalem: Kiryath Sepher.

Schuchardt, Hugo. 1884. Slavo-deutsches und Slavo-italienisches. Graz: Leuschner \& Lubensky.

Shur, Shimon A. 2000. gdud meginéy hasafá beérets israél 1923-1936 (The Language Defendants Regiment in Eretz Yisrael 1923-36). Haifa: Herzl Institute for Research and Study of Zionism.

Singler, John Victor. 1995. The Demographics of Creole Genesis in the Caribbean: A Comparison of Martinique and Haiti. In: Jacques Arends (ed.), 203-32. The Early Stages of Creolization, Amsterdam - Philadelphia: John Benjamins.

Taube, Moshe (Max). 1984 [1989]. Langues avoir, langue être et le yiddish. Orbis (Bulletin international de Documentation linguistique) 33 :222-35.

Thomason, Sarah G. \& Terrence Kaufman. 1988. Language Contact, Creolization, and Genetic Linguistics. Berkeley: University of California Press.

Torczyner, Naphtali Herz. 1938. 'milím sheulót bilshonénu' (Loanwords in Our Language). Lеšonénu 9: 5-30.

Ullendorff, Edward. 1997. Review of Nakdimon Shabbethay Doniach \& Ahuvia Kahane, 1996, editors of The Oxford English-Hebrew Dictionary, Oxford: Oxford University Press. Bulletin of the School of Oriental and African Studies 60: 557-9.

Van Coetsem, Frans. 1988. Loan Phonology and the Two Transfer Types in Language Contact. Dordrecht: Foris.

Van Coetsem, Frans. 2000. A General and Unified Theory of the Transmission Process in Language Contact. Heidelberg: Winter.

Weinreich, Uriel, William Labov \& Marvin Herzog. 1968. Empirical Foundations for a Theory of Language Change. In: Winfred P. Lehmann \& Yakov Malkiel (eds.), 97-195. Directions for Historical Linguistics, Austin: University of Texas Press.

Whorf, Benjamin Lee. [1941] 1956. Language, Thought, and Reality. Selected Writings of Benjamin Lee Whorf (edited by John B. Carroll). Cambridge (Massachusetts): Massachusetts Institute of Technology Press.

Wimsatt, William C. 1999a. Genes, Memes and Cultural Heredity. Biology and Philosophy 14: 279310.

Wimsatt, William C. 1999b. Generativity, Entrenchment, Evolution, and Innateness. In: Valerie G. Hardcastle (ed.), 139-79. Biology Meets Psychology: Constraints, Connections, Conjectures. Cambridge (Massachusetts): Massachusetts Institute of Technology Press..

Winford, Donald. 2005. 'Contact-Induced Changes: Classification and Processes'. Diachronica 22: 373-427.

Zelinsky, Wilbur. [1973] 1992. The Cultural Geography of the United States: A Revised Edition. Englewood Cliffs (New Jersey): Prentice Hall.

Zuckermann, Ghil'ad. 1999. Review of Nakdimon Shabbethay Doniach \& Ahuvia Kahane 1998, editors of The Oxford English-Hebrew Dictionary, Oxford: Oxford University Press. International Journal of Lexicography 12: 325-46.

Zuckermann, Ghil'ad. 2003. Language Contact and Lexical Enrichment in Israeli Hebrew. London: Palgrave Macmillan. 
Zuckermann, Ghil'ad. 2004. Cultural Hybridity: Multisourced Neologization in "Reinvented" Languages and in Languages with "Phono-Logographic" Script. Languages in Contrast 4: 281-318.

Zuckermann, Ghil'ad. 2005. "Abba, why was Professor Higgins trying to teach Eliza to speak like our cleaning lady?": Mizrahim, Ashkenazim, Prescriptivism and the Real Sounds of the Israeli Language. Australian Journal of Jewish Studies 19: 210-31.

Zuckermann, Ghil'ad. 2006a. Complement Clause Types in Israeli. In: Robert M. W. Dixon \& Alexandra Y. Aikhenvald (eds.), 72-92 (Chapter 3). Complementation: A Cross-Linguistic Typology (Explorations in Linguistic Typology, vol. III), Oxford: Oxford University Press.

Zuckermann, Ghil'ad. 2006b. Direct and Indirect Speech in Straight-Talking Israeli. Acta Linguistica Hungarica 53.4: 467-81.

Zuckermann, Ghil'ad. 2006c. A New Vision for Israeli Hebrew: Theoretical and Practical Implications of Analysing Israel's Main Language as a Semi-Engineered Semito-European Hybrid Language. Journal of Modern Jewish Studies 5.1: 57-71.

Zuckermann, Ghil'ad. 2008a. Israelit safá yafá (Israeli, a Beautiful Language: Hebrew as Myth). Tel Aviv: Am Oved.

Zuckermann, Ghil'ad. 2008b. "Realistic Prescriptivism": The Academy of the Hebrew Language, its Campaign of "Good Grammar" and Lexpionage, and the Native Israeli Speakers. Israel Studies in Language and Society 1.1: 135-154.

\section{Abbreviations}

$\begin{array}{llll}\text { A } & \text { transitive subject } & \mathbf{n} & \text { noun } \\ \text { ACC } & \text { accusative } & \text { NEG } & \text { negator } \\ \text { AMB } & \text { ambitransitive verb of the } & \text { NP } & \text { noun phrase } \\ & \text { S=A type } & \mathbf{O} & \text { transitive object } \\ \mathbf{C} & \text { consonant } & \mathbf{p l} & \text { plural } \\ \mathbf{C} & \text { (immediately followed by a } & \mathbf{P O S S} & \text { possessive } \\ & \text { number) century } & \mathbf{P R O X} & \text { proximal demonstrative } \\ \text { CONSTR } & \text { construct-state } & \mathbf{S} & \text { intransitive subject } \\ \mathbf{C O P} & \text { copula } & \mathbf{S A E} & \text { Standard Average European } \\ \text { DEF } & \text { definite article } & \mathbf{S g} & \text { singular } \\ \mathbf{E} & \text { extended intransitive } & \mathbf{T R} & \text { transitive verb } \\ \mathbf{E X I S} & \text { existential ('existential copula') } & \mathbf{V} & \text { vowel } \\ \mathbf{f} & \text { feminine } & \mathbf{X} & \text { either a consonant or a vowel } \\ \mathbf{I N T R} & \text { intransitive verb } & & \\ \mathbf{m} & \text { masculine } & & \end{array}$

\section{A note on the transcription:}

whereas $a$ is primary stress, $a ̀$ is secondary stress;

$k h$ stands for $[\chi]$ and $s h$ for $\left[\int\right]$. 